\title{
Why the Nebra Sky Disc Dates to the \\ Early Bronze Age. An Overview of the Interdisciplinary Results
}

\author{
Ernst Pernicka \\ Jörg Adam \\ Gregor Borg \\ Gerhard Brügmann \\ Jan-Heinrich Bunnefeld \\ Wolfgang Kainz \\ Mechthild Klamm \\ Thomas Koiki \\ Harald Meller \\ Ralf Schwarz \\ Thomas Stöllner \\ Christian-Heinrich Wunderlich \\ Alfred Reichenberger
}

\begin{abstract}
It is not unusual that archaeological finds come under renewed scrutiny. This is actually an important part in the progress of scientific research. All the more so when important and ground-breaking discoveries are involved, like the Nebra Sky Disc, which is listed among the UNESCO "Memory of the World". However, in most cases a new assessment is based on new data or insights. None of this is presented in a recently published article by Gebhard and Krause (2020). Instead, their argument is based on early published and unpublished material, which is used and cited selectively and ignores a substantial number of subsequent publications. Since the Nebra Sky Disc is a unique find that was not recovered during a controlled excavation, it can neither be dated by traditional typological methods nor prima facie by its appearance. Moreover, there is no scientific method yet available to date copper alloys exactly, so that the date suggested in the original publication was established by reconstructing the find context and by analysing the accompanying finds that are typologically and radiocarbon dated to around $1600 \mathrm{BC}$. The find location on the Mittelberg was excavated in great detail and a number of scientific analyses confirmed the testimony of the looters in a court trial that the Sky Disc had been buried there together with the accompanying finds. These analyses also disproved an earlier claim that the Sky Disc was a modern fake. This allegation is not repeated by Gebhard and Krause (2020) but they do use similar arguments for their claim that the Sky Disc was not found together with the hoard and may not even
\end{abstract}

have been on the Mittelberg near Nebra. By contrast, they assert that the Sky Disc should be typologically dated to the Iron Age. It can be shown that their arguments are based on a distortion of the evidence derived both in the court trial and by scientific analyses. They combine their proposal with a superficial typological discussion of the image displayed on the Sky Disc. As this overview demonstrates, through interdisciplinary studies it is possible to determine the origin and composition of the Nebra hoard with the greatest possible certainty. This determination was based on results from sediment attachments, the chemical concentrations of gold and copper in the geological subsoil of the findspot, astronomical references, as well as an analysis of the traces left by the looters, police investigations, and a comprehensive confession by the offenders, which has confirmed the independently obtained archaeological and scientific observations.

\section{Keywords}

Nebra Sky Disc, find context, Early Bronze Age, authenticity, archaeology, archaeometry, soil pedology/geology.

Zusammenfassung - Warum die Himmelsscheibe von Nebra in die Frübbronzezeit datiert. Überblick über die interdisziplinären Ergebnisse

Es ist nicht ungewöhnlich, dass archäologische Funde einer erneuten Prüfung unterzogen werden; dies ist eigentlich ein wichtiger Teil im Fortschritt der wissenschaftlichen Forschung. Umso mehr gilt das, 
wenn es sich um wichtige und bahnbrechende Entdeckungen handelt, wie die Himmelsscheibe von Nebra, die in das UNESCO-Weltdokumentenerbe („Memory of the World“) aufgenommen wurde. In den meisten Fällen beruht eine neue Beurteilung jedoch auf neuen Daten oder Erkenntnissen. Nichts davon findet sich in einem kürzlich veröffentlichten Artikel von Gebhard und Krause (2020). Stattdessen stützt sich ihre Argumentation auf früh veröffentlichtes und unveröffentlichtes Material, das selektiv verwendet und zitiert wird und eine beträchtliche Anzahl von Folgepublikationen ignoriert. Da es sich bei der Himmelsscheibe von Nebra um einen einzigartigen Fund handelt, der nicht bei einer kontrollierten Ausgrabung geborgen wurde, kann sie weder mit traditionellen typologischen Methoden noch prima facie nach ihrem Aussehen datiert werden. Zudem gibt es noch keine wissenschaftliche Methode zur exakten Datierung von Kupferlegierungen, so dass die in der Originalpublikation vorgeschlagene Datierung durch die Rekonstruktion des Fundkontextes und durch die Analyse der Beifunde, die typologisch und radiokohlenstoffdatiert um 1600 v. Chr. liegen, ermittelt wurde. Der Fundort auf dem Mittelberg wurde sehr detailliert ausgegraben und eine Reihe von wissenschaftlichen Analysen bestätigten die Aussage der Raubgräber in einem Gerichtsverfahren, dass die Himmelsscheibe dort zusammen mit den Begleitfunden vergraben lag. Diese Analysen widerlegten auch eine frühere Behauptung, dass die Himmelsscheibe eine moderne Fälschung sei. Diese Behauptung wird von Gebhard und Krause (2020) zwar nicht wiederholt, aber sie verwenden ähnliche Argumente für ihre Behauptung, dass die Himmelsscheibe nicht zusammen mit dem Hort und vielleicht nicht einmal auf dem Mittelberg bei Nebra gefunden wurde. Stattdessen behaupten sie, dass die Himmelsscheibe typologisch in die Eisenzeit datiert werden sollte. Es lässt sich zeigen, dass ihre Argumente auf einer Verzerrung der sowohl im Gerichtsverfahren als auch durch wissenschaftliche Analysen gewonnenen Beweise beruhen. Sie verbinden ihren Vorschlag mit einer oberflächlichen typologischen Diskussion des auf der Himmelsscheibe dargestellten Bildes. Wie dieser Überblick zeigt, ist es durch interdisziplinäre Studien möglich, Herkunft und Zusammensetzung des Nebra-Horts mit größtmöglicher Sicherheit zu bestimmen. Diese Bestimmung basiert auf den Ergebnissen von Sedimentanhaftungen, den chemischen Konzentrationen von Gold und Kupfer im geologischen Untergrund der Fundstelle, astronomischen Referenzen sowie einer Analyse der von den Raubgräbern hinterlassenen Spuren, polizeilichen Ermittlungen und einem umfassenden Geständnis der Täter, das die unabhängig gewonnenen archäologischen und wissenschaftlichen Beobachtungen bestätigt hat.

\section{Schlüsselbegriffe}

Himmelsscheibe von Nebra, Fundkontext, Frühbronzezeit, Authentizität, Archäologie, Archäometrie, Bodenkunde/Geologie.

\section{Introduction}

The Nebra Sky Disc is one of the most important archaeological finds of the past century. It is widely accepted that it displays the world's earliest known concrete representation of astronomical phenomena. Its cultural significance is also reflected by its inclusion into the UNESCO "Memory of the World" register in June 2013. However, since the Sky Disc, together with a number of accompanying metal objects known as the Nebra hoard, was not recovered in a controlled archaeological excavation, doubts have occasionally been raised concerning the authenticity of the Sky Disc and if it was actually found together with the metal objects that undisputedly can be dated to the developed central European Early Bronze Age around 1600 BC. ${ }^{1}$ These doubts were thoroughly rebutted in a judicial trial against the looters and the antiquities dealers at the Regional Court in Halle in 2005 and, after completion of the appeals procedure, in a scientific article. ${ }^{2}$ Since then a number of further investigations have widened and consolidated the culture-historical setting of the Nebra Sky Disc. ${ }^{3}$ Most of the results of these investigations are widely scattered in different specialist journals, conference proceedings, and books, because the ramified research comprised many different disciplines. It is not possible and was never our intention to define an endpoint of the research on the Sky Disc, but a volume including a summary of the insights gained over the last fifteen years is in preparation.

This overview was triggered by a recently published claim that it is more likely that the Sky Disc was not part of the Nebra hoard and, based on stylistic arguments, should be dated to the Iron Age. ${ }^{4}$ It is also mentioned there that the new assessment was made "on the basis of sources that are more difficult to access" and that the "underlying sources were published only insufficiently or not at all”. As it turns out, these sources are partly out of date and represent the state of the art at the beginning of the investigations of the Nebra hoard. Nevertheless, Gebhard and Krause present an interpretation of the find context and the associated

1 This began with a letter from Peter Schauer to the 'Frankfurter Allgemeine Zeitung' on 30.11.2004, followed by SCHAUER 2005a, using almost identical arguments against the Mittelberg site as now. - Compare Gebhard, Krause 2020.

2 Judgement of the Regional Court Halle 2005: LG Halle 2005. Pernicka et al. 2008.

3 Two conference volumes, nine dissertations and dozens of articles on the Sky Disc and its cultural environment have emerged from the DFG research group FOR550 alone: Meller, Bertemes 2019, 15-19 with a bibliography of the articles published since 2004 within the respective project groups of the FOR550. - See also Bertemes 2019, 21-32.

4 Gebhard, Krause 2020. - Almost identical arguments were published by the same authors in a book on alleged Middle Bronze Age gold and amber finds from Bernstorf, Freising district, Bavaria (GebHard, Krause 2016), which strangely enough gives the Nebra Sky Disc a conspicuously wide scope. These arguments do not seem to have been given much consideration among relevant specialists. The Bernstorf finds have meanwhile been exposed as forgeries, see Pernicka 2014b and the following consistently negatively assessed reviews of Gebhard, Krause 2016: Ernée 2017. - Harding, Hughes-Brock 2017. - Jung 2017. - Pernicka, Wunderlich 2017. - Reichenberger 2017. - Weiss 2017. 


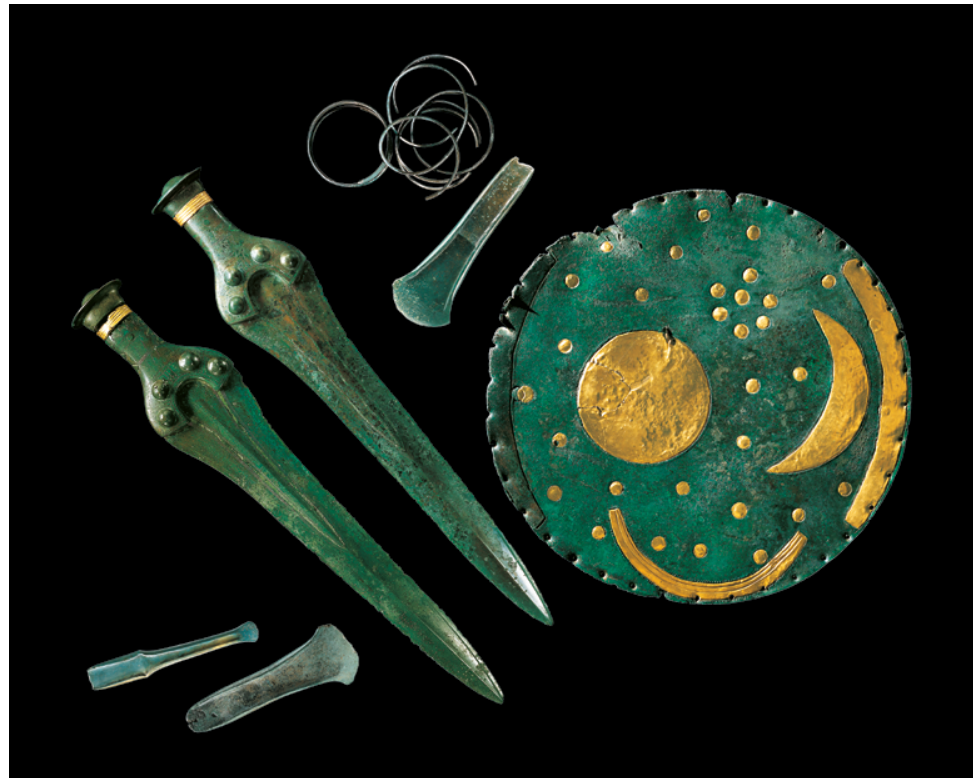

Fig. 1. The Nebra hoard with the Sky Disc, two swords, two axes, one chisel and two arm spirals after restoration (Photo: J. Lipták, Munich).

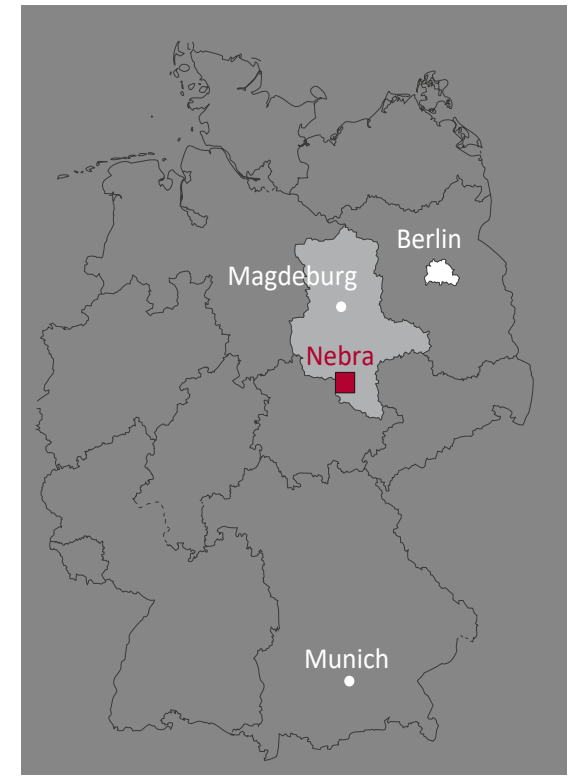

Fig. 2. Map with the Nebra site

(B. Janzen, LDA). scientific analyses which is essentially a rehash of the arguments put forward by Peter Schauer, ${ }^{5}$ with the important difference that the Sky Disc is no longer seen as a modern forgery but as an archaeological object from a different site that may be dated to the Iron Age. Three major arguments are used for this interpretation, namely the divergent reports of the two looters who uncovered the hoard, minor differences in samples of adhering soil on three objects of the hoard including the disc, and differences in the chemical and lead isotope compositions of the objects in the hoard.

In the following, these arguments are dealt with in the same order. They resemble, as mentioned, the same arguments put forward to support an earlier allegation that the Sky Disc was a modern forgery, which were effectively refuted in a comprehensive article in the 'Archäologisches Korrespondenzblatt'. ${ }^{6}$ Inevitably, these results must in parts be taken up again, but new images and new arguments in the light of more than a decade of research are presented.

5 Schauer 2005a. - Schauer 2005b.

6 Pernicka et al. 2008. - Compare with the judgement of the Regional Court Halle 2005 (LG Halle 2005) and Riederer 2016, 307 : "I am convinced about the authenticity of the disc and the origin of the disc in the Bronze Age because the scientific arguments presented (the type of metal, the type of patina, the technological characteristics, the results of the isotope and lead-210 analyses) have a conclusive force that cannot be refuted" (published in German, translated by the authors).

\section{The Find Context of the Nebra Hoard}

On 4 July 1999, two looters discovered an Early Bronze Age hoard on the Mittelberg hill near Nebra, Burgenlandkreis (Saxony-Anhalt), which consisted of two swords, two axes, one chisel, and two arm spirals as well as a bronze disc which was almost completely covered with adhering soil (Figs. 1-2, 12, 15). After the initial and improper cleaning of this disc, an image consisting of gold inlays was revealed. A few days later, the looters sold the entire find to the first dealer. Almost three years later, the Sky Disc and other objects from the hoard were recovered in a Swiss hotel and seized by the authorities. Subsequent police investigations were able to track down the missing pieces as well as localising the findspot.

The discovery of the Nebra hoard with the Sky Disc, its illegal excavation and later recovery by the authorities ${ }^{7}$ has been described in detail several times and need not be repeated here. ${ }^{8}$ The looters were convicted in a first court trial and gave testimony in a second trial before the Regional Court in Halle against the two antiquities dealers who last had the hoard in their possession. In the course of the interrogations, one of the looters, Mario Renner, cast doubt on

7 The disc was seized by the Basel police on 23 February 2002, i.e. some two and a half years and not four years after its discovery as suggested by Gebhard, Krause 2020, [1].

8 LG Halle 2005, esp. 6-18. - Meller 2010a, 24-31. - Schöne 2015, esp. 12-99. - Meller, Michel 2018, 24-51. 
the narrative of his accomplice Henry Westphal in a book which was written by two ghostwriters. ${ }^{9} \mathrm{He}$ described both the place of discovery and the composition of the hoard as being made up of different finds. However, in court Renner himself described this book as a merely fictitious report in which the find situation is not authentically reported.

The facts of the case were extensively and thoroughly assessed by the $10^{\text {th }}$ Criminal Chamber of the Halle Regional Court, chaired by the presiding judge, Judge Gester, who concluded: "After a comprehensive review of all the evidence, there was no doubt about the find location of the Nebra Sky Disc." In particular, the court paid close attention to the credibility of the witnesses Westphal and Renner and came to the conclusion: "...Based on the impression gained of Westphal during the hearing of 03.06.2005, which lasted several hours, the chamber had no doubt that Westphal faithfully reported the location of the hoard of Nebra." The "dubious insinuations about a possibly completely different find situation" by Renner were, however, judged by the court to be untrustworthy. ${ }^{10}$

It is difficult to understand why Gebhard and Krause rely on such grey literature as the booklet published by Renner as a key witness to support their own interpretation of the find context. Contrary to the conclusions reached by the court trial, they claim that the witness Westphal was influenced by "suggestive questions by archaeologists involved" ${ }^{11}$ Based on this assumption, for which no new evidence is presented, the authors cast doubt on the credibility of this testimony. Instead, they claim that the "original traces of diggings and damage to the disk during its retrieval" ${ }^{12}$ are contradictory. Firstly, they maintain that the shallow depth and the alleged partial storage in humus in which the disc was found should have caused differences in the corrosion of the Sky Disc. The information provided by the looters in this regard must, therefore, be incorrect. ${ }^{13}$ The differences in the corrosion can, however, be explained by the vertical position in the ground (see section 3). Secondly, they claim that the damage to the Sky Disc was not caused by its improper recovery by the looters, but in two separate events at widely different times. ${ }^{14}$ From this it was concluded that the Sky Disc was either initially buried somewhere else or possibly added to the Nebra hoard later. ${ }^{15}$ This would imply that the looters found the disc as well as a set of unique

\footnotetext{
9 RENNER [2005].

10 LG Halle 2005, 21-23 (translated by the authors).

11 Gebhard, Krause 2020, [4].

12 Gebhard, Krause 2020, [2].

13 Gebhard, Krause 2020, [4].

14 Gebhard, Krause 2020, [3-4].

15 Gebhard, Krause 2020, [17].
}

Early Bronze Age swords and the other findings at different locations within a short period of time.

\subsection{The Archaeological Excavation}

The archaeological investigation of the looter's excavation pit took place under the local supervision of Thomas Koiki (State Office for Heritage Management and Archaeology Saxony-Anhalt in Halle, in the following: LDA) between 19 August 2002 and 25 November $2002 .{ }^{16}$ The pit-like feature which was the remnant of the looter's activity was localised according to information provided by the looters themselves and (independently of them) by one of the dealers. It was still recognisable as a shallow depression and located directly next to a charcoal kiln at the incipient northwestern slope area about $50 \mathrm{~m}$ from the centre of an Iron Age enclosure on the top of the Mittelberg. The localisation of the findspot required little effort because of the charcoal kiln, a hunter's stand, and a tree mark made by the looters.

Although a final publication of the excavation report is still in preparation, a plan and two sections with accompanying information and photos have already been published several times (Fig. 3). ${ }^{17}$ This published information should actually be sufficient for any archaeologist to understand the context of the find. The major difference in the interpretation of the find context is the thickness of the humus layer. Gebhard and Krause estimate it, based on Josef Riederer's suggestion, to have been $15 \mathrm{~cm}$ (Fig. 4). ${ }^{18}$ However, the looters always spoke of a 3-5 cm-thick humus layer, ${ }^{19}$ consistent with the situation found at the Sky Disc's findspot (Fig. 5). A thicker topsoil deposit can indeed be found a few metres away from the findspot. However, this is the result of a medieval to early modern charcoal kiln located here (Fig. 6). ${ }^{20}$

After the removal of the forest soil, which varied in thickness between approx. 6 and $8 \mathrm{~cm}$ in the immediate undisturbed surroundings, a brown to dark grey-brown, almost circular discolouration (4b) with a diameter of $90-100 \mathrm{~cm}$ emerged in the first subsoil level (Bv horizon) (see Fig. 3). Within this feature there was a darker, round to oval core area (4a) filled with decaying foliage, small twig fragments

16 The excavation has been published in PERnicka et al. 2008, 332 334. - Meller 2010a, 35-45. - Meller 2013, 496-499.

17 Pernicka et al. 2008, 332-334, 333 and Figs. 1-2. - Meller 2010a, 35-44, 36-37 and Figs. 4, 6. - Meller 2010b, 78-83. - Meller 2013, 496-499, 498 and Figs. 5-6.

18 Gebhard, Krause 2020, [4]. - Already stated in Gebhard, Krause 2016, 30-31. - Riederer 2016, 309.

19 This is correctly cited in Gebhard, Krause 2016, 27 and GebHARD, KRAUSE 2020, [4] with footn. 8 referring to "Trial minutes RA Thommen" (correct: Thom-Eben).

20 Mentioned, for instance, by Pernicka et al. 2008, 332. - Meller 2010a, 43, 37 and Fig. 6a. 

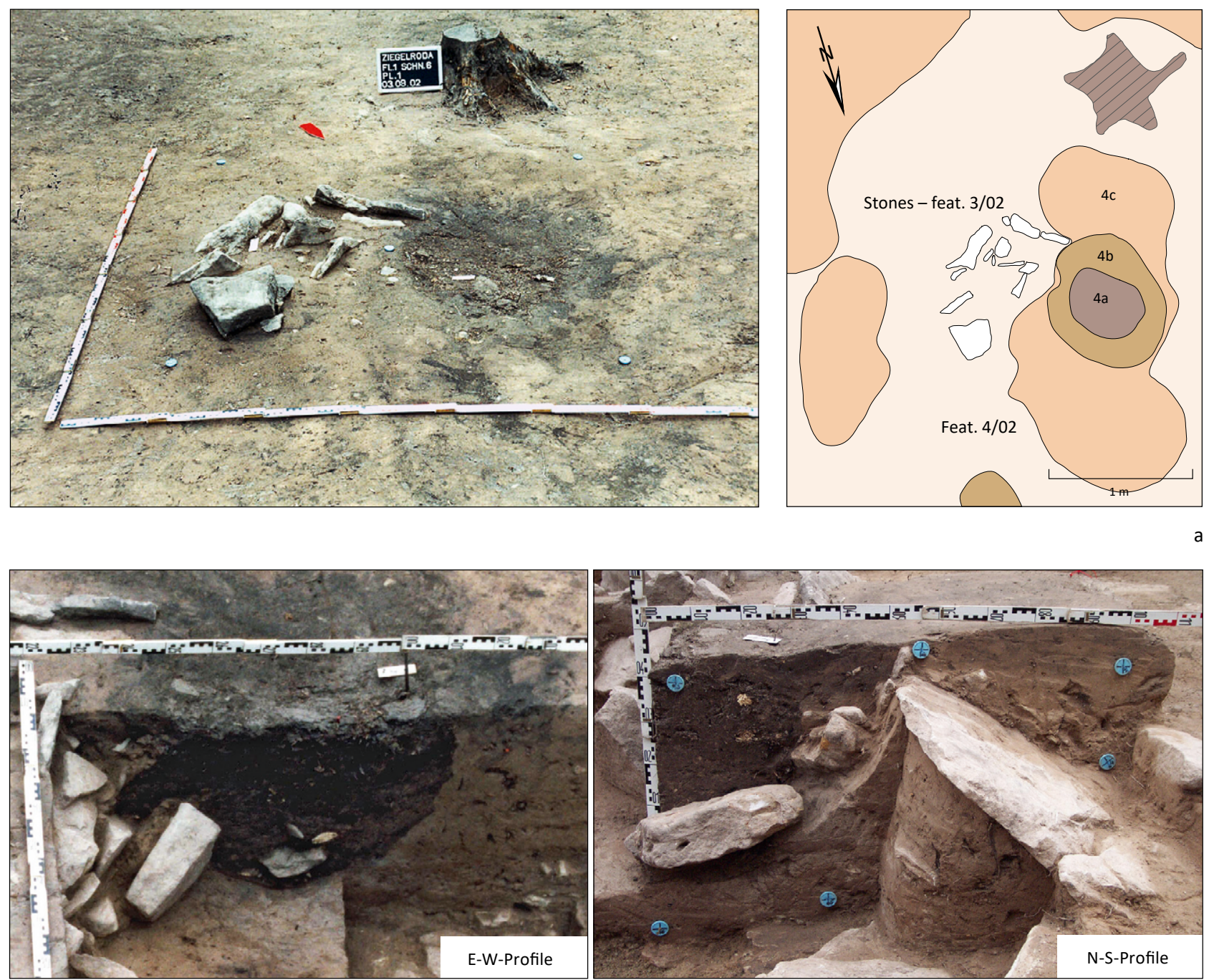

Looting Pit - feat. 4/02 C B

$\begin{array}{lll}\text { Profile }- \text { no. } 30 \quad \text { E } & \text { B } & \text { Feat. 4/02 }\end{array}$
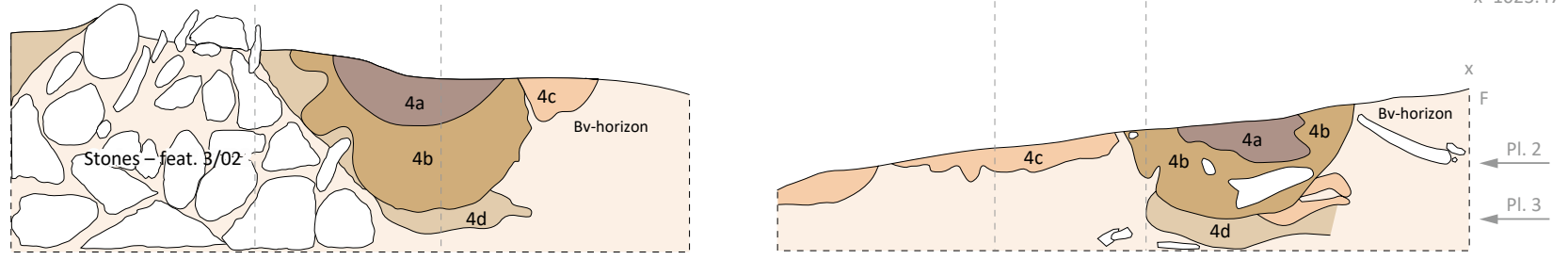

Fig. 3. Archaeological documentation of the looter's pit feature 4/02 on the Mittelberg near Nebra 2002. - a. Planum in a photo (left) and drawing (right). - b. East-west section (left) and north-south section (right) in photo and drawing. The pit-like feature consists of three layers (4a-c). The core (4a) consisted of fresh leaves, wood, and humus remains. The surrounding pit filling (4b) contained less recent organic components. In contrast to the adjacent material of the humification horizon, the area around the pit (4c) had a brown colour. Below the pit, high copper and gold concentrations could be measured in an undisturbed, banded clay layer (4d) (see Fig. 8). The stone packing east of the pit could be identified as a natural geological phenomenon (MelLER 2013, 498 and Figs. 5-6). 


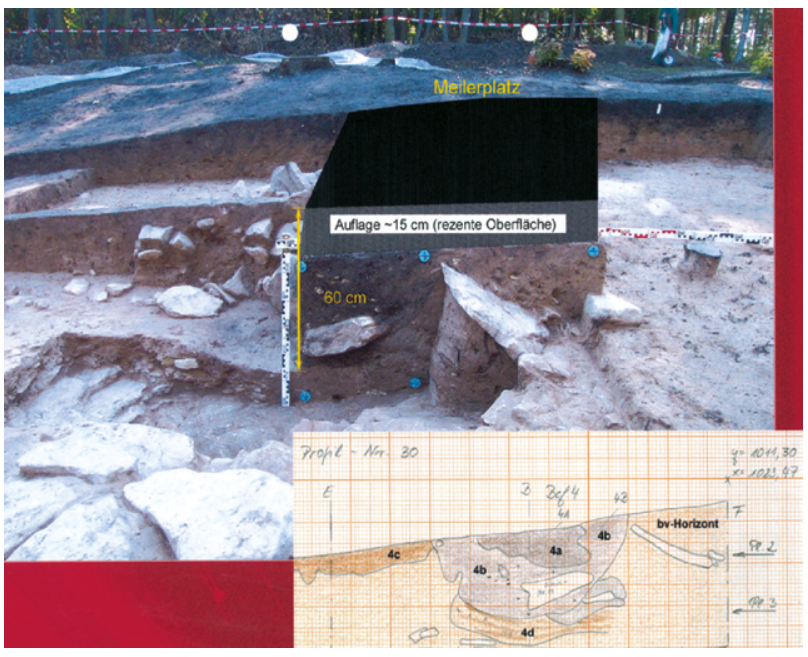

Fig. 4. On the excavation photo, which was made available to the court by the LDA, Gebhard and Krause reconstructed the topsoil structure above the looters' pit with a thickness of $15 \mathrm{~cm}$ (GEBHARD, Krause 2020, [3] and Fig. 2c). However, the thin humus layer had already been removed when this photograph was taken. Even here it becomes visible that the schematic drawing (grey) lies entirely within the browning horizon of the section behind it. However, the thickness is augmented by the remains of a charcoal pile, which is why the black layer is actually thicker here (GEBHARD, KRAUSE 2020, [3] and Fig. 2c).

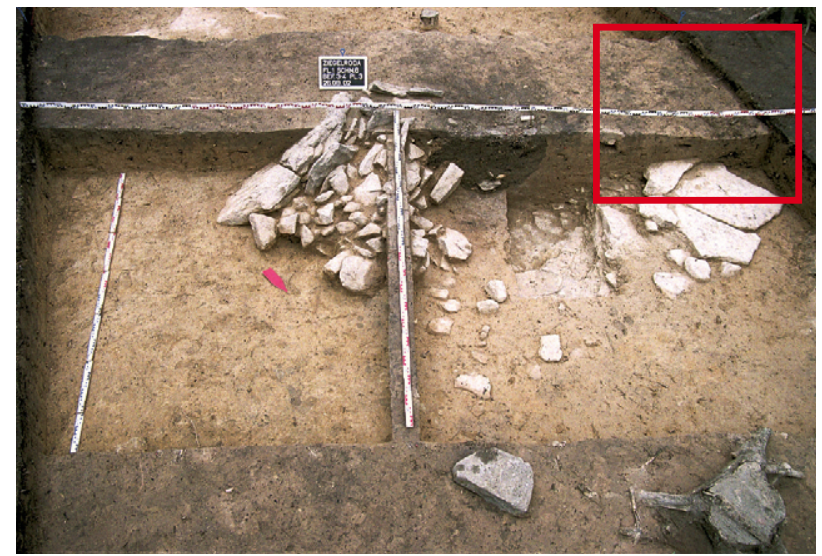

Fig. 5. The photograph shows the looters' pit with the adjacent stone packing from a different perspective. On the right edge of the photo we see the northwestern section (see plan Fig. 6), which is located opposite the charcoal pile on the southeastern section (see Fig. 4). After removal of the foliage, the humus layer (Ah horizon) measured only about $5 \mathrm{~cm}$ (red box) (Meller 2010a, 36 and Fig. 4, adapted by B. Janzen, LDA).

and humic sand. This core feature had dimensions of about $45 \times 56 \mathrm{~cm}$. In the area surrounding the actual pit, the otherwise light-brownish yellowish material of the humification subsoil horizon was discoloured to a brownish shade (4c). This irregular, shapeless feature had vague boundaries and measured about $2.50 \times 0.80 \mathrm{~m}$ from south to north. Because it was only a few centimetres deep it was interpreted as being the result of the looter's diggings.

Immediately to the east of the findspot, stones were discovered which appeared to be tightly packed. At first this was treated as an anthropogenic feature but this interpretation had to be corrected in the course of the excavation work. ${ }^{21}$ Later it was found that this was a natural geological feature, among other things because of its contact with the bedrock and numerous frost cracks on the stone slabs. ${ }^{22}$

The soil (4b) on the edge of the fill of the looter's pit was altogether less humic than the core area (4a), reaching about $30 \mathrm{~cm}$ deep, and also contained less foliage and fewer twigs. Moreover, the proportion of loamy sand was higher. As a result, the soil had a lighter hue and was partly mottled. Occasionally, charcoal particles were found which probably derived from the adjacent charcoal pile. The remains of leaves and twigs prove that the backfilling of the pit could not have taken place a very long time ago. The greatest depth of the feature is $60 \mathrm{~cm}$ below the top edge of the humus. The pit's edge is very irregular, its contour is partly bulged, partly rounded, then again polygonal with short straight sections.

During the excavation of the backfilled material from the southeastern part of the pit, the very irregular pit wall, which was interspersed with small pieces of sandstone, was carefully exposed. Some vertical, narrow, $3-8 \mathrm{~cm}$-long longitudinal grooves were interpreted as possible traces of hammer blows. According to the investigations by the public prosecutor the hoard find was uncovered with a modified fire brigade pickaxe. The two most distinct impact marks were cast in plaster and thus preserved.

Directly below the looter's pit a brown to reddish-brown, weakly banded, maximally $10 \mathrm{~cm}$-thick, irregular discolouration (4d) was found. The consistency of the sandy material corresponded to that of the C-subsoil horizon. The banding was probably caused by the relocation of clayey or humic material from the original prehistoric feature, which had been completely destroyed during the looter's 'excavation'. Through this the former context could be reconstructed at least indirectly.

Two soil sections were investigated, each at a distance of $15 \mathrm{~m}$ from the findspot of the Sky Disc (soil profile KA 142a

21 Still wrongly reported in MeLler 2002, 18, but corrected in Meller 2013, 498.

22 KaInZ, KLAmm in prep. 


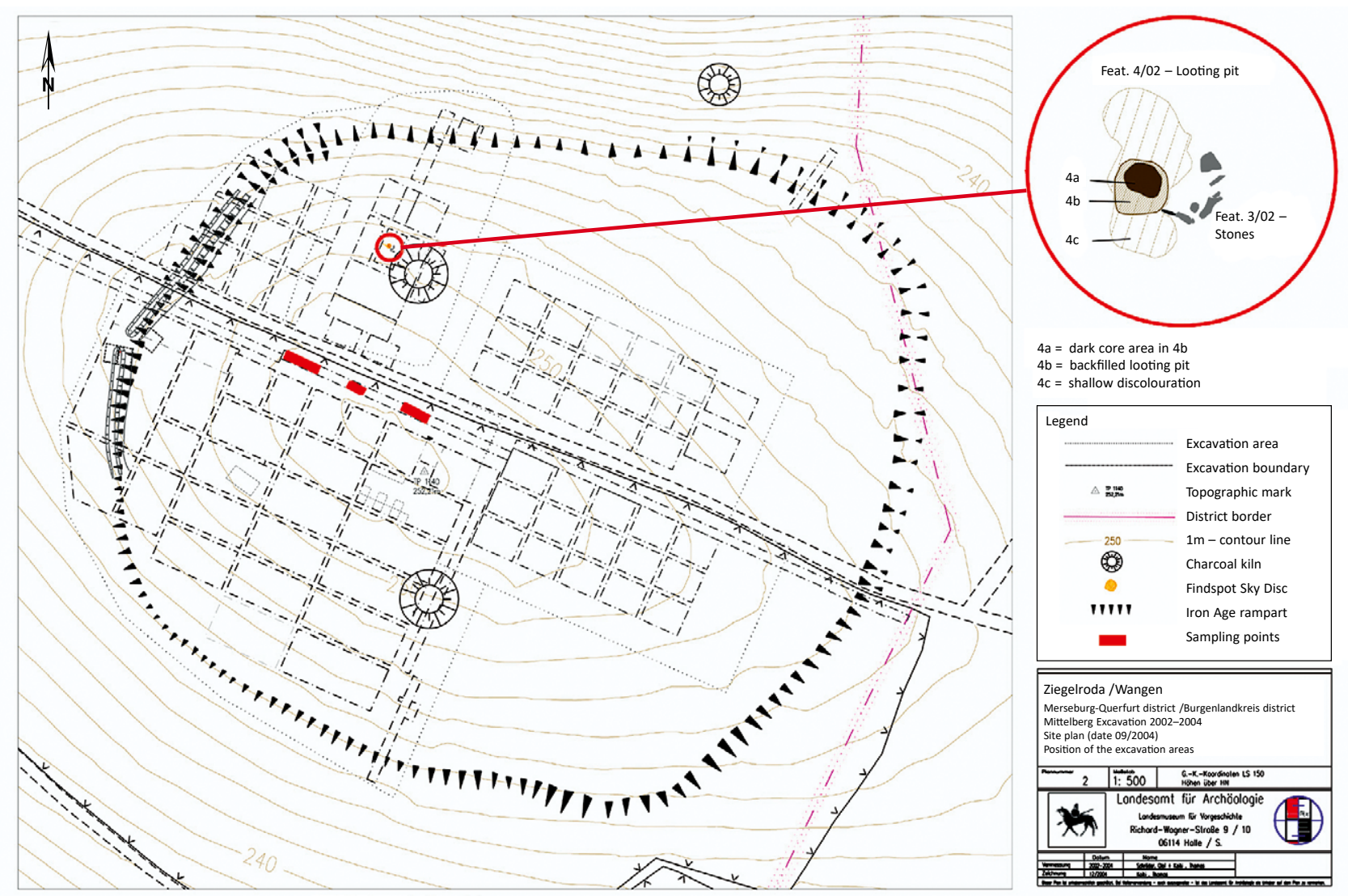

Fig. 6. The location of the looting pit within the Iron Age rampart on the Mittelberg (feature 4/02, red circle). Southeast of the feature, the remains of a medieval or early modern charcoal pile were documented. The sampling sites of reference samples for the determination of the background concentrations of copper and gold in the local sediment are marked as red rectangles south of the looting pit (MELLER 2010a, 37 and Fig. 6a).

and $142 \mathrm{~b}){ }^{23}$ The soils are characterised by brunification and clay leaching (brown albeluvisols) and developed in layers of moderately silty to moderately loamy sand above sandstone. The clay-enriched horizons consist of sandy loam. The thickness of the layers above the bedrock varies between 45 and $65 \mathrm{~cm}$. The fact that these layers are so thin is explained by early Holocene soil erosion, which is evidenced by the presence of relocated soil material in the adjacent dry valleys. However, soil erosion and soil relocation (section KA 142a) also took place after albeluvisol formation and brunification, which is the reason for the near-surface location of the Sky Disc. If the Sky Disc had been re-embedded in the course of this soil relocation, it would have been found lying horizontally. ${ }^{24}$

23 Kainz, KLAmm in prep.

24 Its vertical position when found, but also the fact that it lay in an artificial pit, contradicts the purported secondary position postulated by Gebhard, Krause 2020.
The observed thickness of the humic topsoil was $5 \mathrm{~cm}$ in the neighbouring anthropogenically unaffected soil section, corresponding to the find circumstances. Certainly, the pit, in which the disc was once buried, was refilled with the excavated soil, which consisted mainly of light-coloured subsoil. Except for a small fraction of humus that was added during the refilling process, the material originally surrounding the disc consisted of the light-coloured subsoil, which, according to the photos taken shortly after the discovery, adhered firmly to the disc. ${ }^{25}$ It can also be assumed that the Sky Disc originally lay in the area of the clay leaching, the result of which was documented under the pit (feature $4 \mathrm{~d}$ ). ${ }^{26}$ Hence, the Sky Disc was buried in a pre-existing brown albeluvisol. No traces of bleaching or leaching were observed within the topsoils and brown soil horizons. Thus, younger humic or clayey coatings could not form on the Sky Disc.

25 See Meller 2010a, 32 and Figs. 1a, 1c.

26 Когкі 2006, 8 and Fig. 13/4d. 
Subsequently, due to the slight slope and former erosive types of land use (grazing, trampling etc.), a moderate and small-area differentiated soil erosion took place. Also, the Iron Age rampart on the Mittelberg was flattened due to erosive processes. ${ }^{27}$ It can therefore be assumed that the disc was initially buried deeper in the ground than it appeared at the time of discovery, and would therefore certainly not have come into contact with the thin 'forest humus' that was newly formed on the surface of the terrain after embedding and after later soil erosion.

In summary, the testimony of the looters, the surface quality of the Sky Disc at the time of discovery according to the photos, and the soil conditions on the Mittelberg are entirely consistent.

\subsection{The Authenticity of the Find Context}

Finally, there can be no doubt about the exact identification of the site for a number of other reasons. The LDA's investigations also independently confirm the aforementioned statements of the looters made before the public prosecutor's office and before the court in a further series of essential points:

- A shattered mineral-water bottle of the type 'Deutscher Brunnen' was found in the looter's pit. This bottle type had been in use since the end of the 1960s in West Germany, but its presence would be very unusual in the former GDR. ${ }^{28}$ The appearance of such a bottle on the Mittelberg can thus hardly be expected to date before 1989. The wear and tear on the shoulder of these returnable bottles provides an indication of the length of time it was in circulation, namely about a year, as criminological investigations have shown. It was therefore most likely deposited not before 1990, but later. The looters confirmed in court - without knowing that a water bottle had been found during the re-excavation by the LDA Halle - that they had smashed such a bottle and thrown the fragments into the pit.

- Imprints of the tool used by the looters were identified in the section of the pit. ${ }^{29}$ The tool in question was a fire brigade pickaxe (Fig. 7), ${ }^{30}$ which was presented to the court in Halle and also confirmed by the testimony of the looters, who admitted that they had used it to excavate the hoard, and in doing so damaged the Sky Disc.

27 Meller 2010b, 82-83.

28 Pernicka et al. 2008, 334. - Meller 2010a, 38. - Meller 2010b, 78-79.

29 Cf. Pernicka et al. 2008, 333 and Fig. 2 (with the pertinent section photo).

30 Meller 2010a, 36 and Fig. 5b; 38. - Meller 2010b, 79.

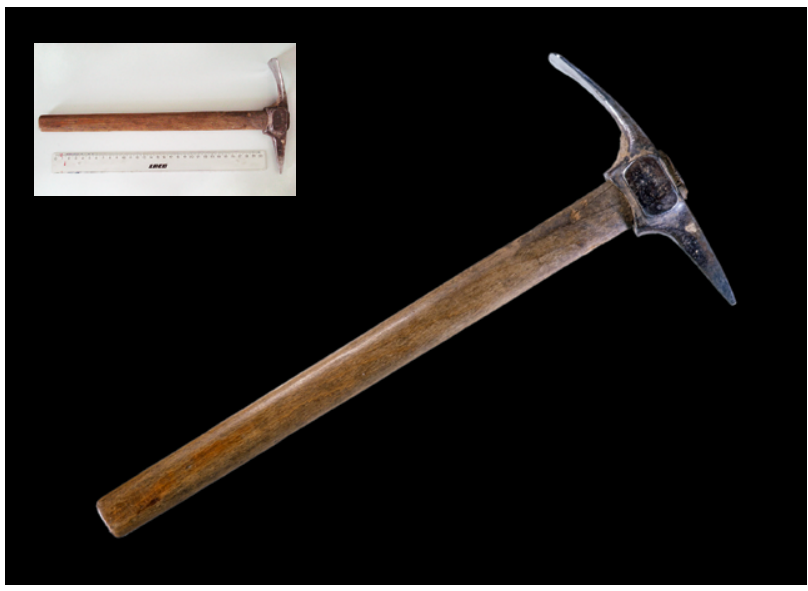

Fig. 7. With this fire brigade pickaxe the two looters excavated the hoard with the Sky Disc. Traces of the pickaxe could be documented at the limits of the looting pit in the course of the excavation (Large photo: J. Lipták, Munich; cf. MelLer 2010b, 79).

- The analysis of the soil from the looter's pit showed a significant enrichment with copper and gold (Fig. 8). ${ }^{31}$ The most revealing aspect is the fact that the highest concentration of copper $(138 \mu \mathrm{g} / \mathrm{g})$ and a high concentration of gold $(19 \mathrm{ng} / \mathrm{g})$ was found in the undisturbed soil below the pit (feature $4 \mathrm{~d}$ ). This can only be explained by the partial dissolution of copper and gold during corrosion, which was subsequently absorbed in the undisturbed subsoil below. This eliminates the possibility that the pit's fill was contaminated with gold by the looters during their activity. Furthermore, this finding shows that a considerable amount of copper and gold had been buried in the pit for a long period of time. Of course, this time span cannot be quantified, but it is consistent with the fact that a large surface area of copper and gold is present in the Nebra hoard, particularly on the Sky Disc. Only a few finds are known from central Germany for the entire Bronze Age in which gold and bronze objects are combined. Moreover, the gold finds in such cases are often only small Noppenringe (lock rings), the surface of which is too small to leave significant traces in the ground. ${ }^{32}$

\section{Original Position, Corrosion and Damage to the Sky Disc}

The exact position of the Sky Disc within the Nebra hoard can no longer be determined. However, there are two clues: on the one hand, the statements by the looter Westphal (see

31 Pernicka et al. 2008, 342, 345 and Figs. 14-15; 346 and Fig. 16. Gebhard, Krause 2016, 36-37 wrongly claim, however, that this is not transparent from the publication.

32 Meller 2014, 623-628. 


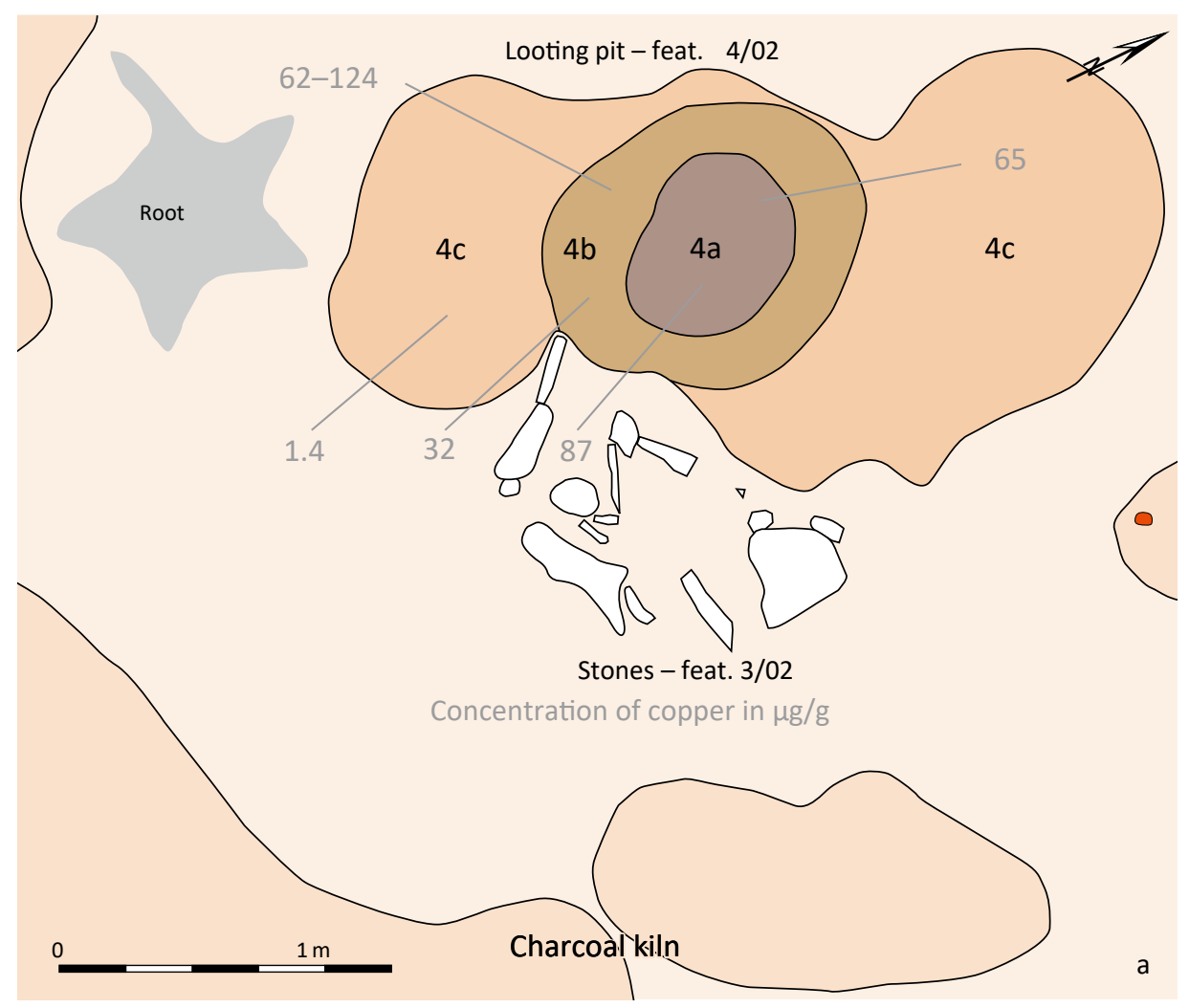

Looting pit - feat. 4/02

Concentration of copper in $\mu \mathrm{g} / \mathrm{g}$

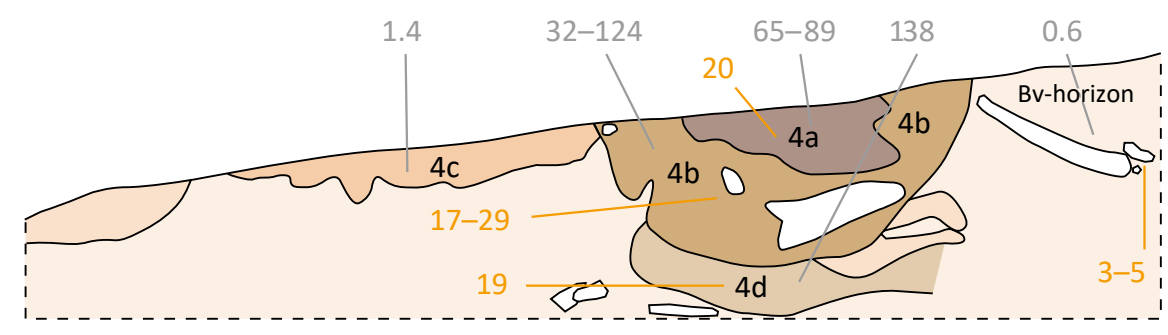

Concentration of gold in $\mathrm{ng} / \mathrm{g}$

$1 \mathrm{~m}$

Fig. 8. Plan (a) and section (b) of the looters' pit (feature 4/02) on the Mittelberg (see Fig. 3) with indications of the measured copper and gold concentrations in the sediment (orange numbers in $\mathrm{ng} / \mathrm{g}$ and grey numbers in $\mu \mathrm{g} / \mathrm{g}$; see Pernicka et al. 2008, 345 and Fig. 14). - The background values for copper are less than $11 \mu \mathrm{g} / \mathrm{g}$ and those for gold are less than $10 \mathrm{ng} / \mathrm{g}$. All samples from the pit (layers $4 \mathrm{a}$ and $4 \mathrm{~b}$ ) show enhanced copper concentrations by two orders of magnitude and simultaneously elevated gold concentrations. These indicate that copper and gold must have been deposited here for a long time. The highest copper concentration comes from the undisturbed layer $4 \mathrm{~d}$ below the find and suggests a leaching of the metals which has accumulated here in the clay-rich sediment (PERNicKa et al. 2008, 345 and Fig. 14).

above); on the other hand, the corrosion of and damage to the object itself. On 26 August 2003 Westphal and Renner, in the presence of their respective lawyers, gave a statement that they discovered the disc $3-5 \mathrm{~cm}$ below the surface. Both declared that the area with the missing horizon arc had been lying uppermost. On 11 May 2005 Westphal prepared a sketch of the find situation (Fig. 9) in the presence of his lawyer and the second looter Renner, according to which the disc stood vertically in the ground, the boat at the lower edge, and the Pleiades at the top. ${ }^{33}$ On 29 May 2005 Westphal reconstructed the find situation on the Mittelberg with

33 Meller 2013, 495-496. 

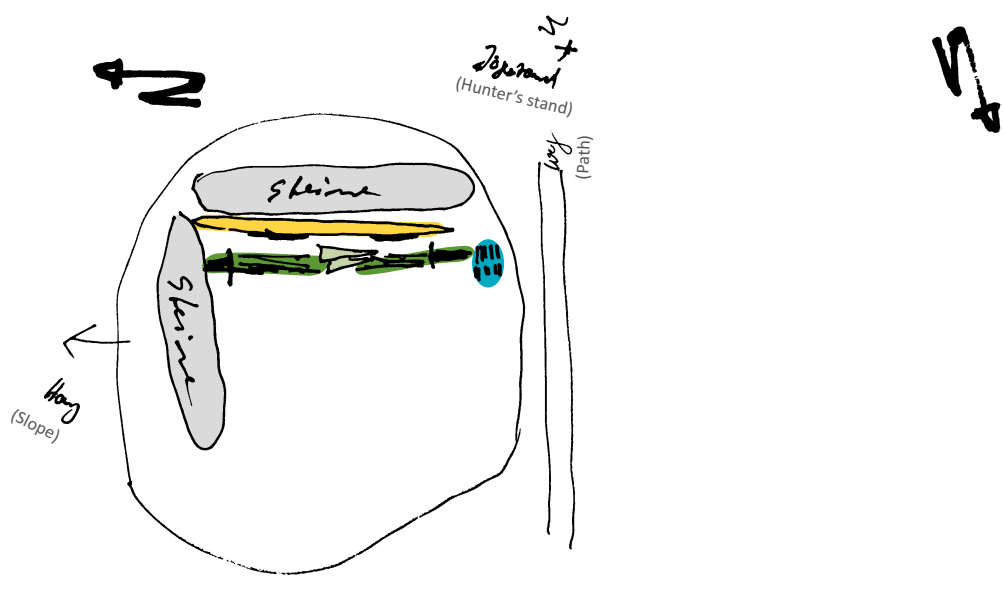

Fig. 9. Already in 2005 the looter, H. Westphal, drew these sketches of the find situation of the Sky Disc hoard. To aid understanding the artefacts have been coloured and transcriptions of the handwriting provided. According to this, the disc stood upright with the ship at the bottom (Meller 2010a, 35 and Fig. 2).

copies $^{34}$ again deviating slightly in relation to the position of the disc, turned clockwise (Fig. 10). These differences manifest the looter's doubts about the exact orientation angle of the disc, but not about its vertical position.

A second line of argument is based on clearly visible damage, as is also argued by Gebhard and Krause. ${ }^{35}$ However, the authors postulate that the damage to the Sky Disc was caused by two different events that occurred at different times. While they attribute the scratches on the left side of the obverse of the Sky Disc to the looting, they speculate that the impacts and deflections on the edge of the Sky Disc are due to an earlier event. The authors claim that the Sky Disc was mechanically damaged once before, at an unspecified time between its deposition and the looting in 1999. Thus, the disc would have been removed from its original burial context and, in an unspecified process, was incorporated into a new context with the accompanying finds. ${ }^{36}$

The authors argue with images taken after the recovery, ${ }^{37}$ in which they claim to have recognised that the damage on the edge was still covered by adhering soil. Gebhard and Krause also suggest that the original position of the Sky Disc during burial can be reconstructed from the type of corrosion, namely that "...in humus and partly in completely different soil, [...] corresponding differences in the patina should be apparent. [...] the evenly thick encrustation of

\footnotetext{
34 Meller 2013, 495-496 and Fig. 22.

35 Gebhard, Krause 2020, [2-4].

36 Gebhard, Krause 2020, [17].

37 Gebhard, Krause 2020, [2] and Fig. 1c; [16] and Fig. 9.
}

the disk indicates its original location in a uniform soil layer" ${ }^{38}$ However, the corrosion on the Sky Disc is not "evenly" thick, as pitting corrosion has been observed only on one half of the disc (Fig. 11). The corrosion of metals is a complex electrochemical process affected by many, partly self-reinforcing parameters. ${ }^{39}$ While under redox reactions in moist soil environments, anodic and cathodic reaction zones spontaneously form on the surface of a metal object (contact corrosion), the anodic zones, where, for example, pitting corrosion occurs, are predominantly formed on the side with less oxygen. ${ }^{40}$ Consequently, as the pitting corrosion observed in the radiography of the Nebra Sky Disc formed in the area where the half moon is located (see Fig. 11), it is likely that this was the lower, oxygen-poor part in a vertical placement of the disc in the soil over a long period of time.

The notches on the disc's edge, and the scratches and tracks on its obverse side only appear in the zone above the half moon, indicating that this half was excavated first while the rest of the disc was still standing vertically in the soil. This position would also explain the abrasion clearly observable on the edge next to the missing horizon

38 Gebhard, Krause 2020, [4].

39 Without claiming to be comprehensive, the following factors shall be mentioned here: the way the metal was worked and used (keyword: 'stress corrosion'), conductive connection with more noble or less noble metals (keyword: 'sacrificial anode', 'contact corrosion'), local changes in soil chemistry, alloy composition, chemical and mechanical surface treatment (patination, polishing), and many more. 40 Evans 1926. 

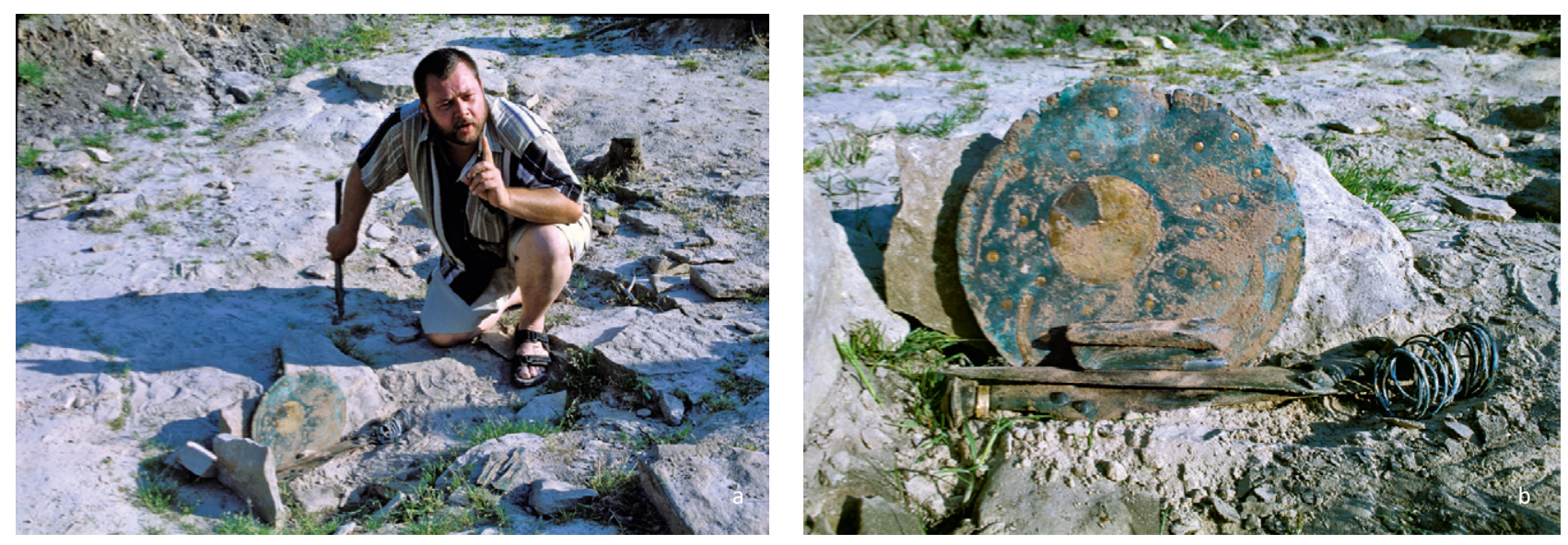

Fig. 10. - a. The looter Henry Westphal re-enacted the find situation on the Mittelberg with replicas in 2005. - b. He arranged the Sky Disc essentially in the same way as he did in the sketch (see Fig. 9). It is turned slightly clockwise (@ LDA Halle, photos: J. Lipták, Munich).

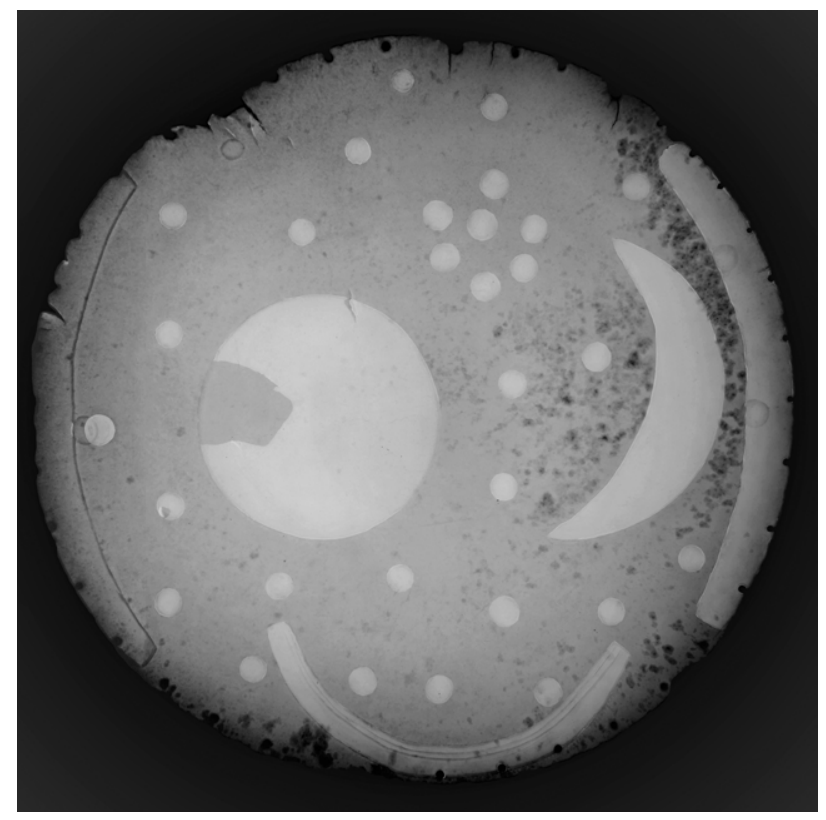

Fig. 11. Radiography of the Nebra Sky Disc. The dark spots, visibly concentrated on the right side, are caused by pitting due to heavy corrosion. The disc is therefore not, as Gebhard and Krause claim, "evenly" corroded (analogue image on X-ray film, mounted from two images, LDA, H. Breuer, 2003; detail already in MeLLer 2010a, 46 and Fig. 14b and Meller 2011, 167).

$\operatorname{arc}$ (Fig. 12). The detailed study of the differential corrosion, surface abrasion, and damage by the looters forms part of the publication of the Nebra hoard which is in preparation. In any case, the exact rotation angle of the disc does not abnegate its vertical position in the soil nor its dating. In summary, there remains some uncertainty on the exact rotation position of the disc in the ground.
With regard to the direction of the impact of the pickaxe used by the looters, ${ }^{41}$ Gebhard and Krause erroneously assume that all blows came from above or from the edge of the disc towards the centre, which is not the case. Rather, the blows came from at least two directions, as shown in Figure 12.

Two types of damage can be recognised: First, the peen of the pickaxe strikes the edge and the obverse of the disc, coming from the upper right, and the peen cuts the metal with notches being formed. As a result of the violent blows, sections of the rim are bent backwards in two places. The vertical orientation described by the looter is consistent with this type of damage. The impacts and scratches have left visible marks in the adhering soil which prove that the damage to the rim is also modern (Fig. 12, blue arrows). Figure 13 shows that the notches, such as those found on the upper edge of the disc, are freshly incised, with the incisions appearing almost like bare metal. If they were of older origin, they should have corroded in the ground.

Due to the impacts, the rim of the disc was bent backwards. During this process, adhering soil also flaked off locally on the obverse, which is visible even in the blurred pictures that Gebhard and Krause have published. However, since the bending of the bronze results in an increase in surface area on the convex side, the soil does not necessarily have to flake off from the entire deformed surface (Fig. 14).

The soil adhering to the concave side of the damaged rim, on the other hand, had to flake off, as shown in Figure 15. The illustration dates from spring 2002, when the find was still at the State Office of Criminal Investigation in Magdeburg and no restoration had taken place.

41 Gebhard, Krause 2020, [2] and Fig. 1 b. 


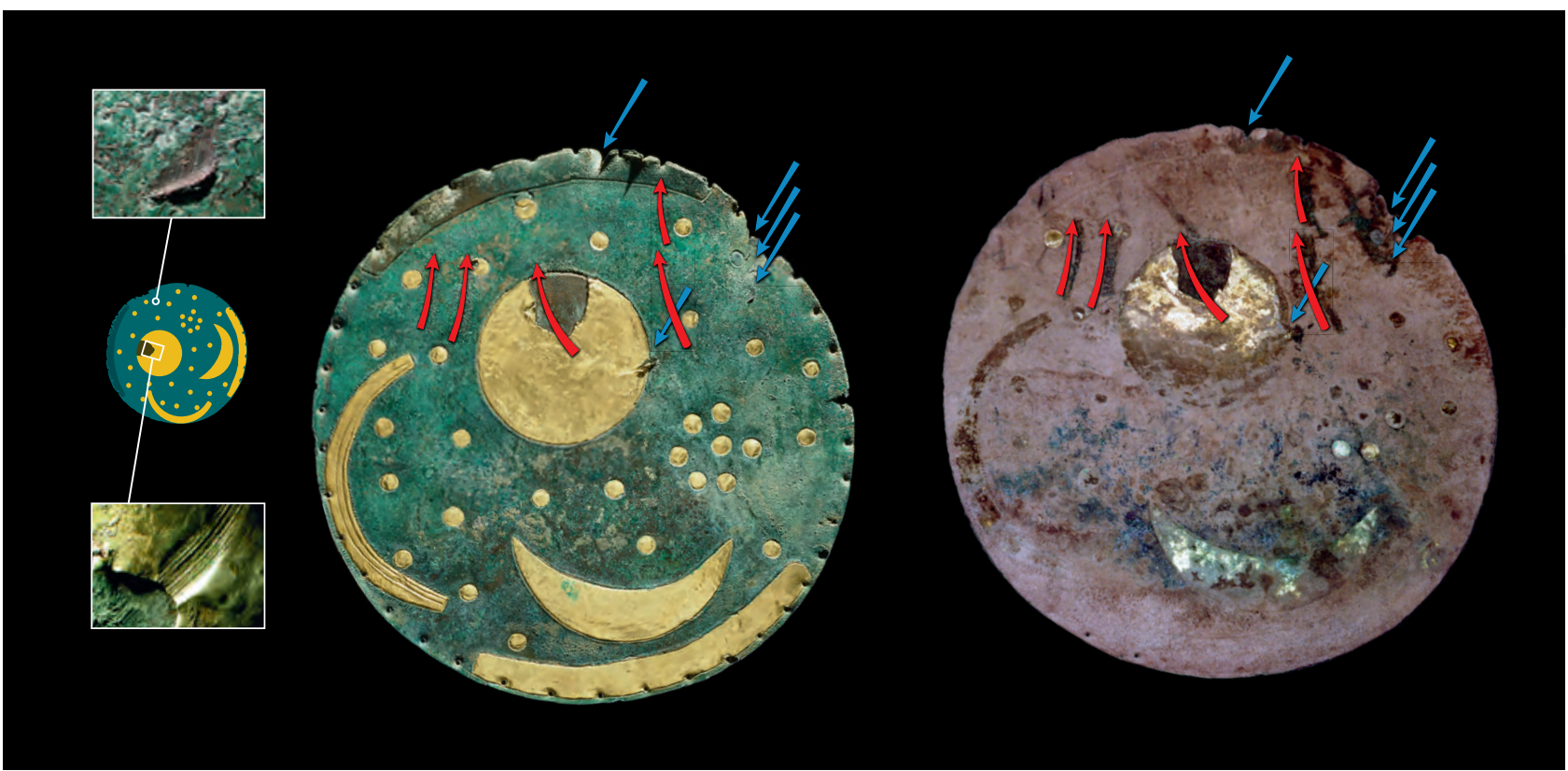

Fig. 12. The traces of the damage on the restored Sky Disc (left side) and the unrestored Sky Disc (right side; from a time when it was still on the illegal antiquities market, showing the same damage [MELLER 2010a, 44 and Fig. 12, cropped]) with the respective directional indications and the corresponding characteristic traces. Two types of damage can be recognised: 1 . The peen of the pickaxe strikes the edge and the disc's surface, coming from the upper right, and the peen cuts the metal with notches being formed. As a result of the violent blows, sections of the rim are bent backwards in two places (blue arrows). 2. The peen hits the disc surface almost perpendicularly to the former blow. The peen then scrapes across the surface, creating wide profiled tracks and part of the gold sheet is torn off and pleated (red arrows). The pulling direction is from bottom to top. This also damaged the star situated next to the sun (Illustration: C.-H. Wunderlich, adapted by B. Janzen, LDA).

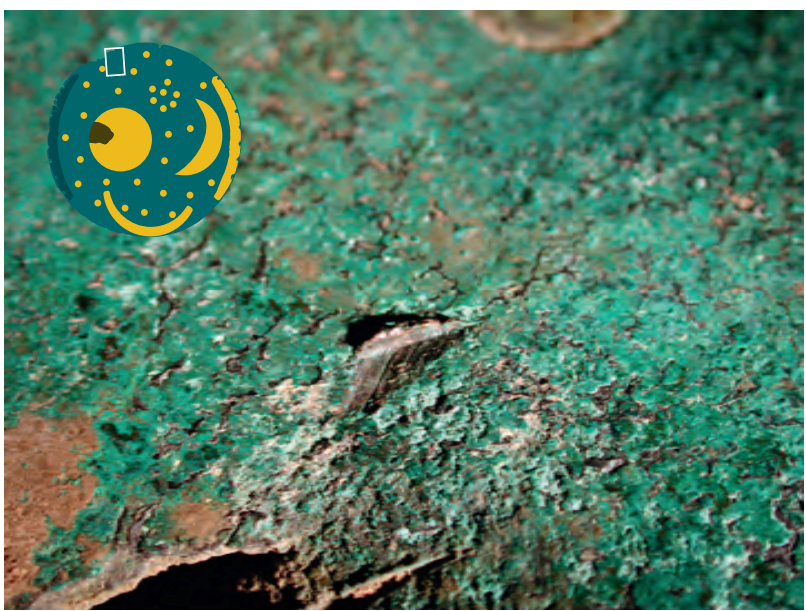

Fig. 13. Recent impact mark on the upper edge of the disc. The green patina that had formed during burial in the soil was broken, exposing the metallic bronze core (Photo: LDA, adapted by B. Janzen, LDA).

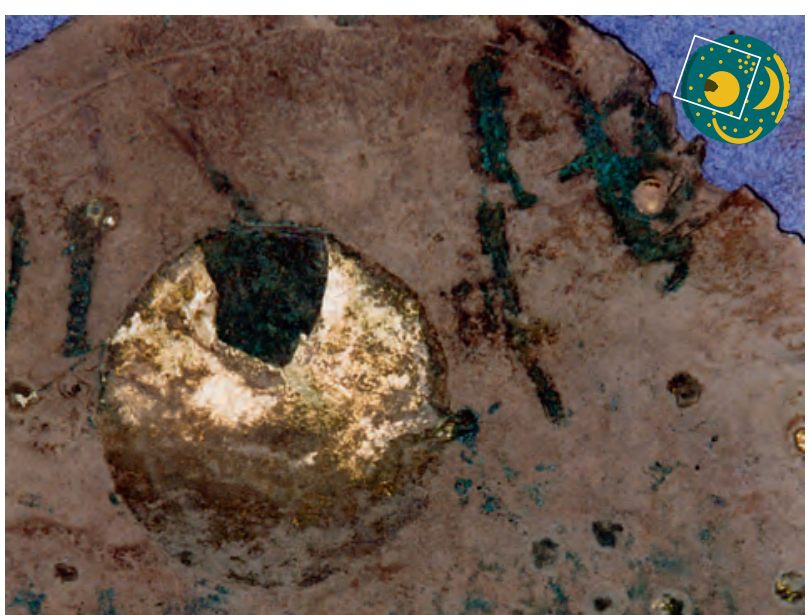

Fig. 14. Image taken by the first dealer. It can clearly be seen that parts of the soil adhesions (e.g. on the right above the star) have flaked off in the area of the damaged edge. These therefore are fresh traces which occurred during the looting (detail from MELLER 2010a, 44 and Fig. 12). 


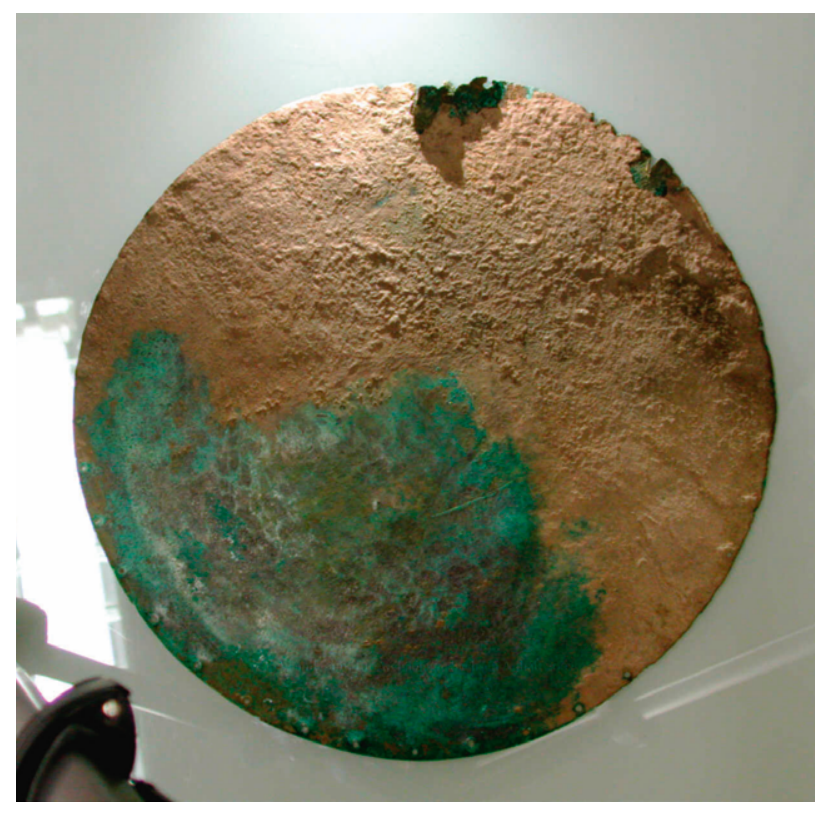

Fig. 15. The reverse of the Sky Disc, image from March 2002 at the State Office of Criminal Investigation in Magdeburg. It is clearly visible that the adhering soil has flaked off at two locations on the upper rim of the disc as a result of impacts with the pickaxe and the resulting bending of the metal. It is obvious that these marks are not ancient. As a result, the assertion by Gebhard and Krause that these traces derive from an earlier relocation of the object can be discarded (Photo: LKA Magdeburg).

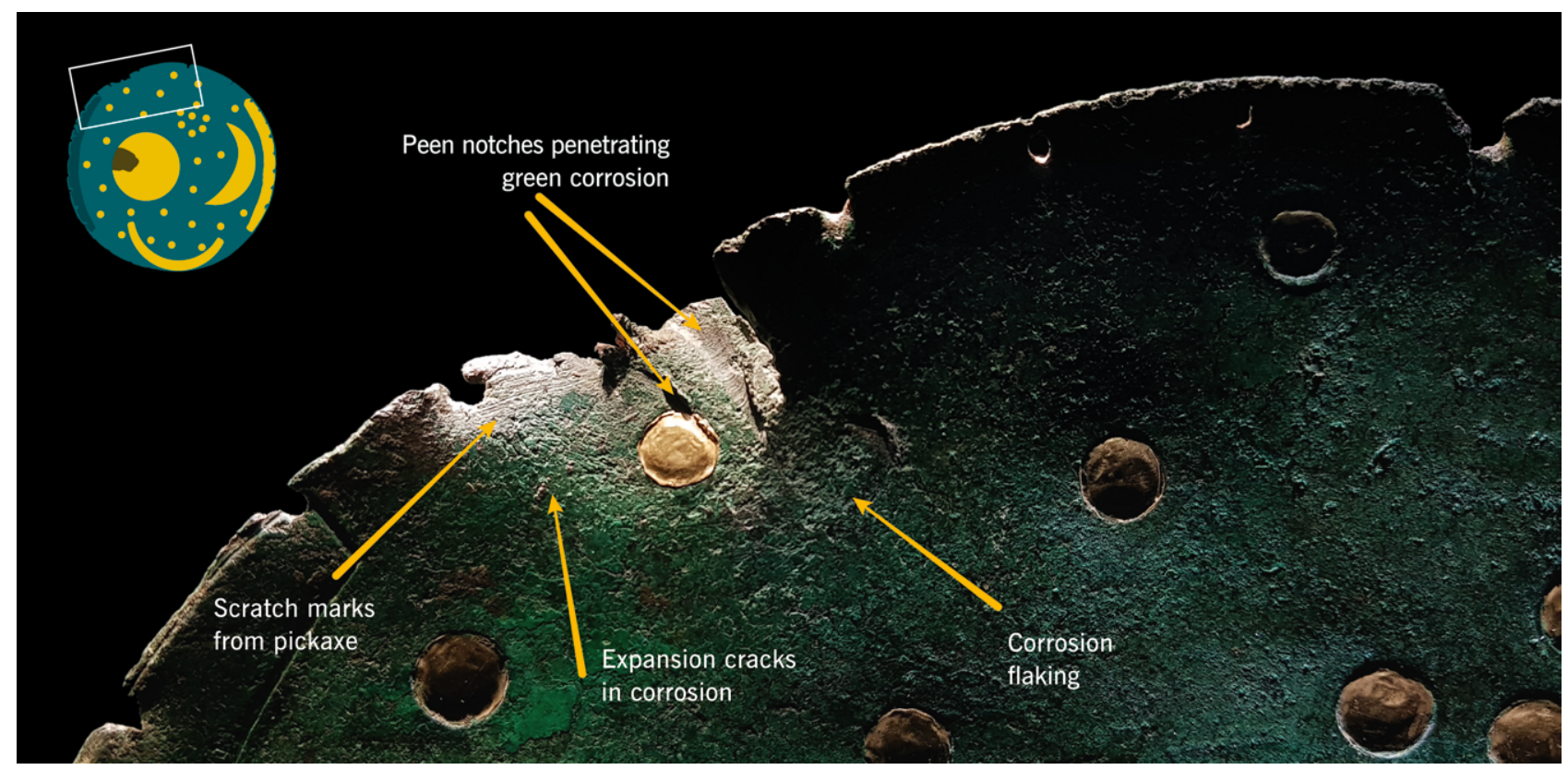

Fig. 16. Upper part of the rim of the Sky Disc, deformed by axe blows with cracks in the corrosion layer and local flaking. The notches of the impacts are also clearly visible. This damage was clearly caused during or shortly after the unearthing and cannot be of older origin (Photo: C.-H. Wunderlich, LDA, adapted by B. Janzen, LDA).

Evidence of bending can also be found in the malachite corrosion. On the obverse, the corrosion layer shows a fine fracture pattern in the form of parallel cracks. This is caused by the surface enlargement on the convex obverse of the warped metal (Fig. 16).

On the reverse the corrosion was compressed, resulting in lighter, thin flakes that are characterised by a lighter appearance (Fig. 17, corresponding to the zones where the soil is flaking in Fig. 15).

Such fine traces, if they had occurred earlier in the ground, would have been overprinted by subsequent corrosion. The theory of Gebhard and Krause that the bending and damage on the rim occurred before the Sky Disc was discovered can therefore be disregarded. 


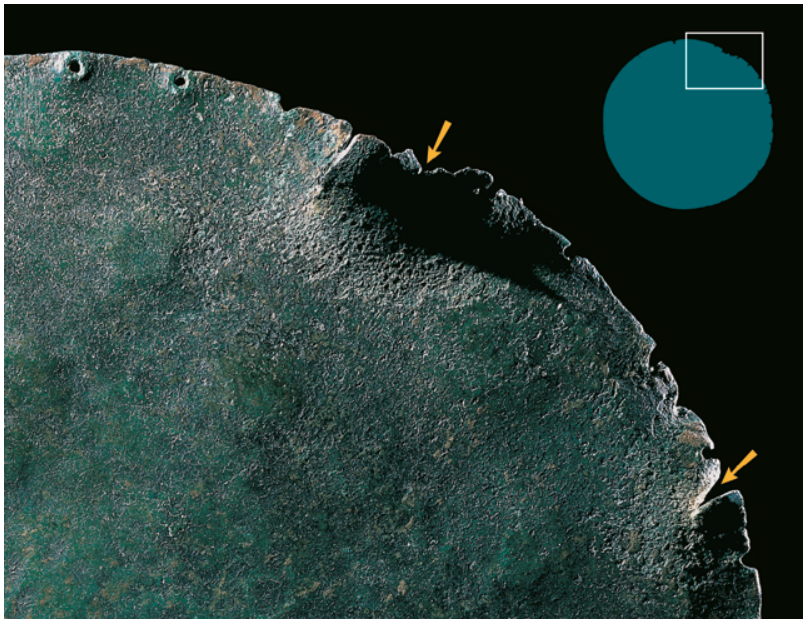

Fig. 17. Reverse of the Sky Disc. Flaking of adhering soil and worn, bright corrosion due to compression of the surface as a result of the axe blows. These traces were clearly induced during or after the looting. These areas also correspond to the areas where adhering soil was removed (see Fig. 15) (Photo: J. Lipták, Munich, adapted by B. Janzen, LDA)

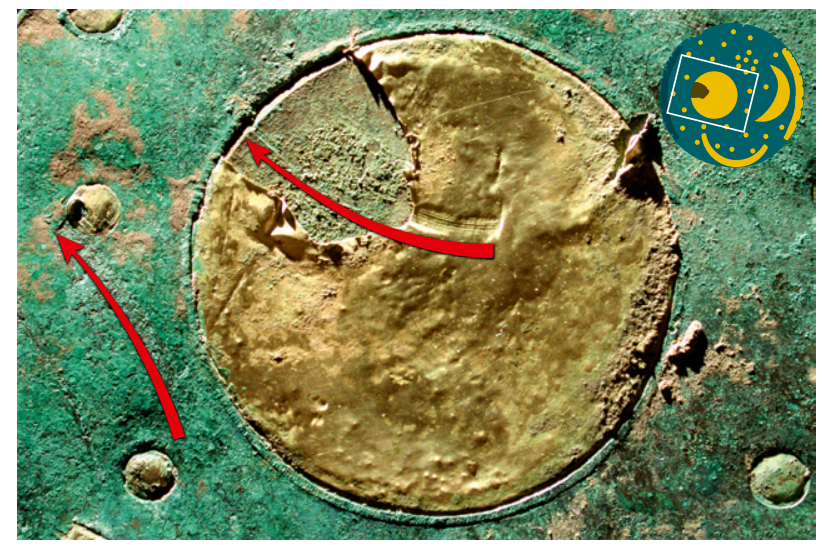

Fig. 18. Photo taken on 27 February 2002 at the State Office of Criminal Investigation in Magdeburg. The arrows mark the course of the scraping movement after the impact of the peen. In the process the firmly adhering soil residue was stripped down to the green corrosion layer. Upper arrow: after the impact (of which the notch above the arrow is the beginning) the peen moved across the gold sheet, leaving the profiled mark. A piece of the gold sheet was torn off, the peen continues to move across the corroded bronze underneath and comes to rest at the groove at the edge of the sun. Lower arrow: The peen passes over the patinated bronze disc, moves across the star, where it leaves a profiled mark, similar to that on the gold disc. Part of the golden star is torn off and pleated at the edge, where the peen comes to a halt (Illustration: C.-H. Wunderlich, LDA, adapted by B. Janzen, LDA).
Second, the peen strikes the disc surface almost vertically and then scrapes upwards across the surface, creating wide profiled tracks, and part of the gold sheet is torn off and pleated. The damage to the star situated next to the sun is caused in a similar way (Fig. 18). During the scraping movements with the peen of the pickaxe, the firmly adhering soil residues were stripped right down to the green corrosion layer (Fig. 12, red arrows). Again, the damage fits with the looter's descriptions.

In sum, a certain variance in the orientation of the disc in the ground is conceivable. This possibility was never denied. On the contrary, from the marks alone, variants of the rotation angle come into consideration. It is essential, however, that at the time of damage the disc must have been standing vertically, a fact that Gebhard and Krause do not dispute. The decisive factor is that the damage was demonstrably caused recently by hitting and pulling with a pickaxe-like tool, in agreement with the judicial reconstruction of the looting process.

\section{Do the Objects of the Nebra Hoard Belong Together?}

Besides the reconstruction of the burial conditions, another topic of the critical discussion by Gebhard and Krause is the question of whether all recovered finds belong and were buried together. This is indeed a crucial question because the only way to archaeologically date the Sky Disc more closely is by the accompanying finds. Two lines of investigation were followed from the beginning of the study of the Nebra hoard, namely the comparison of the adhering soil on the objects with the soil at the findspot and the chemical compositions of all artefacts (see below). Both approaches have now been questioned by the two authors, again based on outdated material, misleading interpretations, and selective citation of published evidence.

\subsection{Soil Samples}

When analysing sediment samples, natural variations are an inherent analytical feature and must be taken into account. The primary sedimentary bedrock succession on the hilltop at the Mittelberg (i.e. the Middle Bunter Sandstone Formation $^{42}$ ) as well as the overlying autochthonous regolith with traces of aeolian loess, and the overlying soil are no exception to this fundamental rule. The bedrock consists of fluviatile sandstone and mudstone with very minor carbonate content, deposited in rivers and creeks, and contains siliciclastic detrital material with both vertically and laterally variable compositions on a m-, $\mathrm{dm}-$, and $\mathrm{cm}$-scale. The natural succession has been disturbed three times, i.e. during the deposition of the Nebra hoard, during the unearthing

42 Klatt, Stelter 2019. 
by the looters, and finally by the archaeological excavation. None of these three disturbances has homogenised the excavated and infilled material and thus minor variations in the mineralogical parageneses and particle size distributions are common and to be expected. It is important to check if samples from a geological location, and from artefact samples to be compared with the former, consist of sediment-petrologically and mineralogically consistent, logical, and plausible parageneses. Only significant deviations from a specific paragenesis would then allow doubts as to the similarity of such samples and could indicate an origin from a spatially and geologically completely different location.

An initial forensic investigation of the adhering soil on the Sky Disc was ordered by the public prosecutor's office in Halle (Saale) in June 2003. A soil sample from the suspected find location of the Sky Disc and a sample from the adhering soil on the disc (see Fig. 12, right side, and Fig. 15) were sent to the Brandenburg State Office of Criminal Investigation. The public prosecutor's office pursued the aim of finding evidence that the Sky Disc was originally buried on the Mittelberg near Nebra, or, if not, of finding evidence of another possible location.

Subsequently and not in immediate conjunction with the initial proceedings, the LDA handed over two further soil samples, which were taken from one of the two swords and one of the two axes (Fig. 19). In addition, six samples from other locations with a similar geological setting were analysed for comparison (Tab. 1) to test how site-specific the similarities between the adhering sediment and the sediment from the Mittelberg were. These samples were obtained from previous forensic investigations in connection with other crimes and thus fulfil the criterion of random sampling of alternative locations.

The methodology used in the investigations and the results have been published in detail. ${ }^{43}$ The most important conclusions are summarised in Table 2. The physical, chemical, and mineralogical investigations revealed almost complete qualitative and extensive quantitative matches between the soil samples VM 1 (soil sample from a depth of approx. $30-40 \mathrm{~cm}$ from the presumed location of the Sky Disc), and Sp 1 (adhesions taken from the Sky Disc), and Sp 2 (adhesions taken from Sword II). The additional

43 AdAm 2019. - At this point it should be emphasised that the method of forensic soil analysis developed by Adam manages with surprisingly small sample quantities, has long been recognised in criminology and has been applied in a large number of criminal cases: ADAM 1984. For example, a forensic soil analysis provided a key indication in a murder trial that ended with a life sentence: Hellmann et al. 2012, 157. - On methodology, see also Murray, Tedrow 1992. Demmelmeyer, Adam 1995 (with numerous further references).

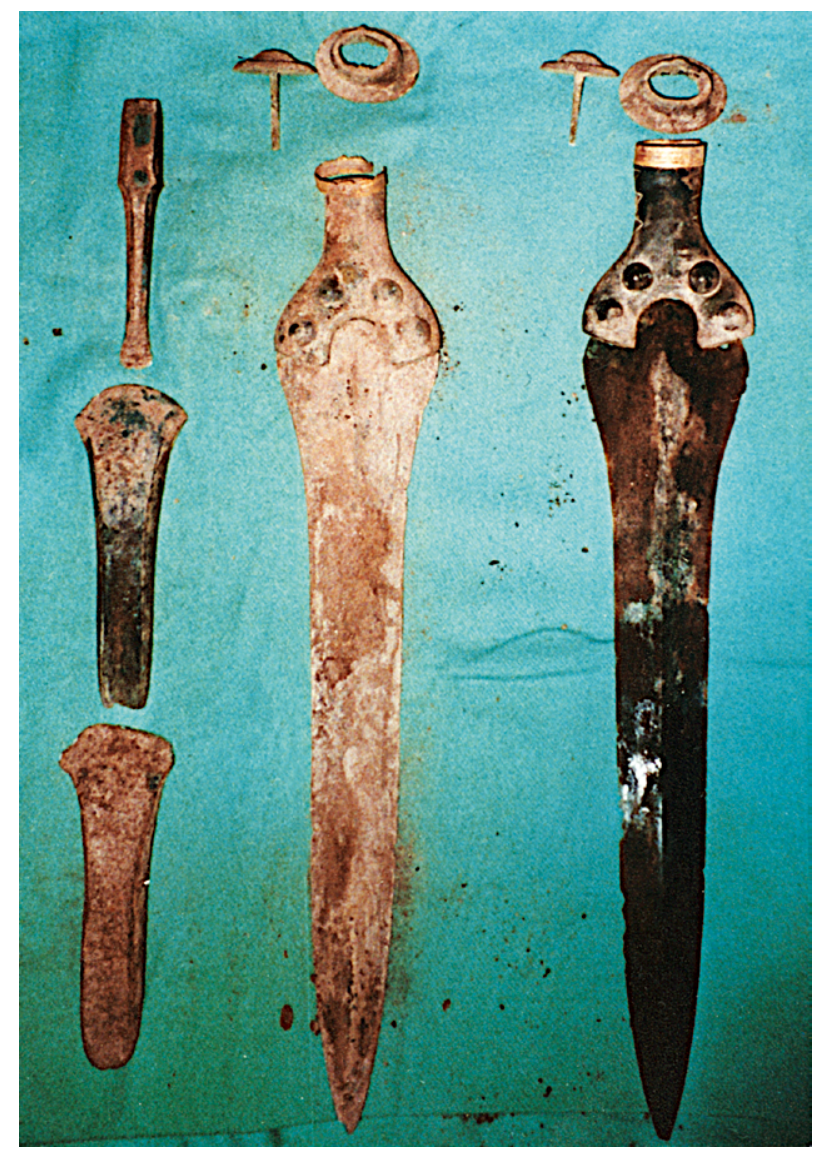

Fig. 19. The other bronze objects of the Nebra hoard were also covered with sediment, as this photo, taken shortly after the recovery, shows. Smaller pieces of adhering sediment have fallen off and collected on the greenish fabric on which the objects were presented. Like the Sky Disc, Sword II also produced extensive agreement with the Mittelberg soil sample, see Adam 2019 (Meller 2010a, 33 and Fig. 1c).

comparison with data from soils which originate from areas that are geologically similar to the find location of VM 1 did not reveal any indications of any possible origin of Sp 1 and Sp 2 other than the Mittelberg near Nebra. All in all, the origin of both the adhering soil on the Sky Disc (Sp 1) and that on the sword ( $\mathrm{Sp} 2$ ) being their presumed location (sampling point of VM 1) is considered as highly probable. However, a statement of certainty is difficult with only one soil sample. For this a detailed investigation of the soil conditions on the Mittelberg near Nebra using a much larger number of reference samples would be required. ${ }^{44}$

A somewhat different statement can be made concerning the soil residues on the axe (Sp 3). A large part of the determined properties and characteristics also indicate an origin

44 This was not part of the mandate for the judicial investigations. 


\begin{tabular}{|c|c|}
\hline Sample designation & Description \\
\hline VM 1 & $\begin{array}{l}\text { Air-dried soil sample, taken from approx. } 30-40 \mathrm{~cm} \text { depth at the presumed location of the Sky Disc on the Mittelberg, } \\
\text { Nebra district, packed in a plastic box, labelled "Mittelberg } 4 \mathrm{c}-30-40 \mathrm{~cm} \text { u. HOK". The net weight was } 70 \mathrm{~g} \text {. }\end{array}$ \\
\hline Sp 1 & Dry, sandy residues, isolated from the Sky Disc with a net weight of $0.113 \mathrm{~g}$, packed in a small plastic vial. \\
\hline Sp 2 & $\begin{array}{l}\text { Dry soil isolated from a bronze sword, packed in a small plastic box, labelled "Sword II from tip". The net weight } \\
\text { was } 0.217 \mathrm{~g} \text {. }\end{array}$ \\
\hline Sp 3 & $\begin{array}{l}\text { Dry soil isolated from a bronze axe, packed in a small plastic box, labelled "Axe HK 2002:1649 C, adhering dirt in the } \\
\text { area of the cutting edge". The net weight was } 0.049 \mathrm{~g} \text {. }\end{array}$ \\
\hline VM S-29 & $\begin{array}{l}\text { Forested area between Jena and Eisenberg, c. } 1 \mathrm{~km} \text { south of Hainspitz (Thuringia), bedrock Middle Bunter Sandstone } \\
\text { Formation. }\end{array}$ \\
\hline VM S-45 & Suhl (Thuringia), c. $1 \mathrm{~km}$ south of the railway station, bedrock Lower Bunter Sandstone Formation. \\
\hline VM S-47/1 & $\begin{array}{l}\text { C. } 5 \mathrm{~km} \text { northeast of Hettstedt (Saxony-Anhalt) in the area of the Wipper River, bedrock Lower and Middle Bunter } \\
\text { Sandstone Formation. }\end{array}$ \\
\hline VM S-47/2 & Collected at a distance of c. $10 \mathrm{~m}$ from VM S-47/1. \\
\hline VM S-58A & $\begin{array}{l}\text { Northern bank of lake Süßer See at the inlet of the Böse Sieben River east of Eisleben (Saxony-Anhalt), bedrock } \\
\text { Lower Bunter Sandstone Formation with loess. }\end{array}$ \\
\hline VM S-58B & Collected at a distance of c. $100 \mathrm{~m}$ from VM S-58A. \\
\hline
\end{tabular}

Tab. 1. Samples examined by J. Adam for the court report.

\begin{tabular}{|l|c|c|c|c|}
\hline Feature & Number of features & \multicolumn{3}{|c|}{ Number of matches } \\
\hline Sample designation & VM 1 & Sp 1 & Sp 2 & Sp 3 \\
\hline Sample description & find location of the Sky Disc & Sky Disc & Sword II & axe \\
\hline 1. General characteristics & 5 & 5 & 4 & 5 \\
\hline 2. Chemical composition & 7 & 4 & 4 & 4 \\
\hline 3. Grain size & 1 & 1 & 0 & 0 \\
\hline 4. Sand fraction & 31 & 30 & 29 & 24 \\
\hline 5. Silt fraction & 81 & 79 & 76 & 68 \\
\hline Total & 125 & 119 & 113 & 101 \\
\hline Agreement in percent & 100 & 95 & 90 & 81 \\
\hline
\end{tabular}

Tab. 2. Characteristics and agreement of the investigated sediment samples from the site and objects found.

from the Mittelberg, ${ }^{45}$ but in comparison to VM 1, Sp 1, and Sp 2 some deviations, like the finer grain size, absence of phyllite, lower proportions of phytholites, increased contents of garnet and anatase can be determined, which may only partly be explained by the small quantity of the test material $(0.049 \mathrm{~g})$. The agreement would be even greater if the presence of malachite in the samples from the artefacts were ignored, because this difference is readily explained by the inclusion of corrosion material.

This means that no differences were observed between the sediments on the Sky Disc and the sword - the key

45 AdAm 2019, esp. 91. evidence for the unity of the hoard - even if the sediments on the axe slightly deviated. Overall, it was established that all three sediment samples (VM 1, Sp 1, and Sp 2) were consistent with a provenance from the Mittelberg. The same possibly applies to $\mathrm{Sp} 3$.

Gebhard's and Krause's assertions that "Neither the analyses of the remaining soil adhesions nor the geochemical analyses of the metals (copper, gold) support a possible coherence of the finds", ${ }^{46}$ and elsewhere, "What is indeed remarkable thereby is that the assessment by J. Adam, which is also central to the argumentation, already determined that

46 Gebhard, Krause 2020, [17]. 
in one case an object was not affiliated with the finds", ${ }^{47}$ are therefore untenable. Rather, the opposite is true.

It may be noted that the $10^{\text {th }}$ Criminal Chamber of the Regional Court of Halle did not consider "the results of the soil experts Dr. Adam and Prof. Dr. Riederer [...] for the determination of the verdict, because they neither absolutely confirm the location claimed by the finders nor make it appear doubtful" ${ }^{48}$ Nevertheless, this cannot be seen as evidence to the contrary.

The clay fractions $(<2 \mu \mathrm{m})$ of sediment adherences from the surfaces of all artefacts from the Nebra Sky Disc hoard and the clay fraction of one comparative sample of the sediment from Mittelberg, near Nebra, were additionally characterised mineralogically by X-ray diffraction (XRD) analyses. In total, more than twenty samples were investigated by XRD analyses. These include four samples, analysed for an expert report to the court by Borg in 2005. ${ }^{49}$ Following the critical comments by Gebhard and Krause, ${ }^{50}$ these early XRD analyses were complemented in 2017, ${ }^{1}$ when the clay fraction of sediment attachments of all artefacts of the Nebra hoard find were additionally analysed by XRD. It should go without saying, but needs to be clarified here, that XRD analyses are not suitable for determining 'soil types' and were never intended as such, as implied by Gebhard and Krause. ${ }^{52}$

The XRD analysis of the clay fraction offers an additional method for determining or estimating the plausibility of the provenance of sediment samples. The method also allows one to check for minerals in the sediment adherences of the artefacts that would conflict with a presumed provenance, i.e. if certain minerals would fit only a specific and especially geologically and mineralogically different bedrock.

The mineral parageneses of the clay fraction of the clastic sediment adherences of the artefacts and of the sediment sample from Mittelberg are largely identical or are logically related to each other in a geological or weathering context. The identified minerals, such as quartz, different feldspars, mica, illite, kaolinite as well as some traces of ankerite and metal hydroxides all represent typical primary minerals or weathering products of felsic siliciclastic bedrocks and possibly some relicts of aeolian loess, as can be expected on top of the Mittelberg. It is important to note that these determined mineral parageneses are typical for the underlying

\footnotetext{
47 Gebhard, Krause 2020, [5], similar also [17].

48 LG Halle 2005, 33.

49 BORg 2005.

50 Gebhard, Krause 2016, 32-37.

51 Borg, Pöllmann, Stöber in prep.

52 Gebhard, Krause 2016, 32-37. - Riederer 2016, 312-317.
}

sandstone-mudstone bedrocks and - on their own - do not allow a precise determination of a certain provenance. However, the determined mineral parageneses from the artefacts generally match the mineral paragenesis from the top of the Mittelberg. Furthermore, there are no paragenetic or mineralogical indications that the sediment adherences from the artefacts would originate from another location, situated on a significantly different type of weathered bedrock, such as crystalline, metamorphic, volcanic, or carbonate rocks.

\subsection{Metal Samples}

From the beginning it was decided to address the question of the affiliation of the objects of the Nebra hoard not only by studying the adhering soil but also by determining their chemical compositions. This was accomplished early on, and the results were included in an unpublished diploma thesis at the Freiberg University of Mining and Technology, ${ }^{3}$ temporarily available on the Internet, which is cited by Gebhard and Krause. Accordingly, all metal artefacts of the Nebra hoard, including the Sky Disc, had a similar chemical composition. They all consist of tin bronze with only copper and tin as major components and similar trace element patterns. This information was already submitted during the court trial and was published in the form of diagrams of the concentrations of silver, gold, nickel, arsenic, and antimony. ${ }^{54}$ It was concluded that the copper of all parts of the hoard originates from the same deposit, but the artefacts are not so similar that they could all have been produced in a single casting process. The trace element pattern is also consistent with Early Bronze Age rib ingots, ${ }^{55}$ and this type of copper was found in a large number of objects that are mainly distributed on the northern foothills of the eastern Alps but extending as far as the Carpathian Basin and southern Scandinavia. ${ }^{56}$ For decades it has also been related to the long-known Bronze Age copper mine of Mitterberg in Salzburg, Austria. ${ }^{57}$ Subsequently it was shown that the trace element pattern of the Nebra hoard does indeed match the copper ores from Mitterberg very well ${ }^{58}$ and this is here demonstrated again in Figure 20. In addition, Manuela Frotzscher was able to show in an extensive study of European copper ores that other deposits could be excluded as suppliers for the copper of the Nebra Sky Disc. ${ }^{59}$

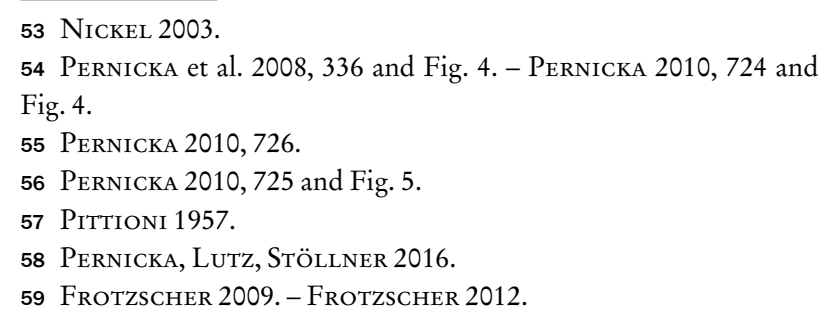



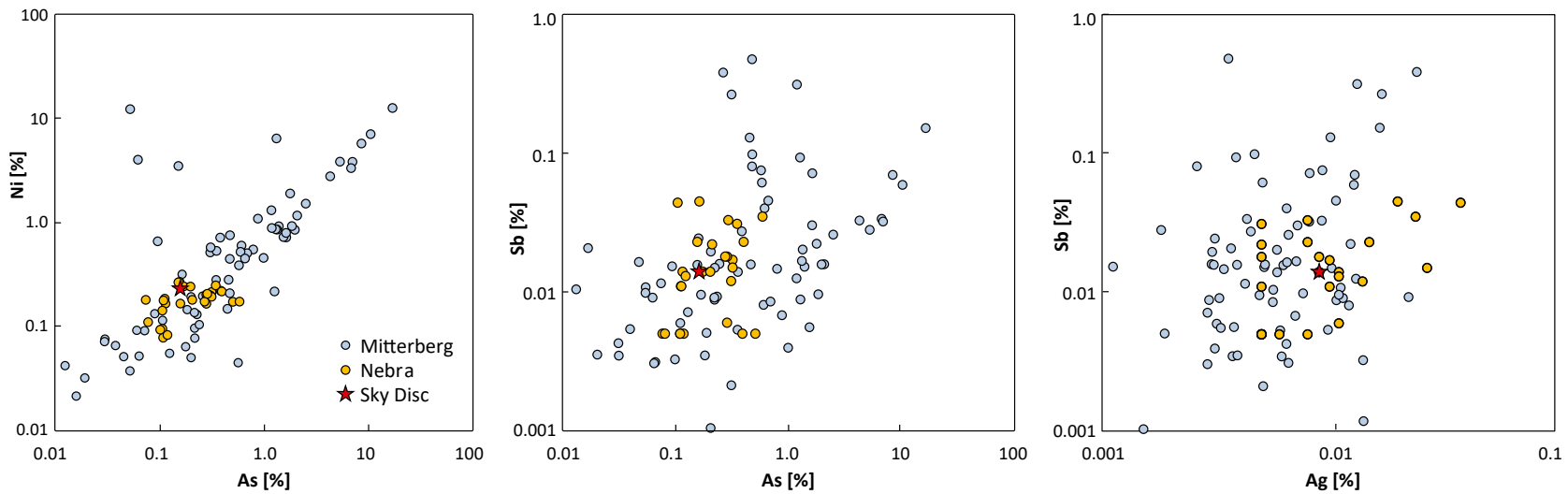

Fig. 20. Trace element concentrations of the objects of the Nebra hoard compared with copper ore samples from the Mitterberg that contain more than $10 \%$ copper. For comparison the concentrations in the ore samples were normalised against copper (E. Pernicka, CEZA Mannheim).

It seems characteristic for the argumentation of Gebhard and Krause that these findings are not mentioned at all. Instead only a very minor difference between the Sky Disc and the other objects of the hoard concerning the zinc concentration is discussed. ${ }^{60} \mathrm{It}$ is manipulative to compare only the reported zinc concentration in the Sky Disc of between 0.1 and $0.2 \%$ that was obtained by energy-dispersive X-ray fluorescence analysis with the low zinc concentrations in the other objects of the hoard obtained by the much more sensitive neutron activation analysis. Using the latter method $0.077 \%$ zinc was also detected in the Sky Disc, which is ignored by Gebhard and Krause. This is still higher than the average $0.0035 \%$ in the accompanying finds, but insignificant. First of all, there is a variation of trace element concentrations in all ore deposits on the micro and macro scale. Secondly, the zinc concentration is a poor indicator of the ore source, since zinc is largely lost during the production of copper metal and indicates the smelting conditions rather than the ore source. Thirdly, an identical composition of all objects cannot be expected because each object was cast in its own right. Actually, this was a strong argument against a forgery that may have used a larger metal stock to produce all of the objects. And finally, the image on the Sky Disc has been altered at least four times so that it may reasonably be assumed that it was produced earlier than the accompanying finds. It is not unusual to find objects of different ages in archaeological contexts. In this case one cannot expect that the Sky Disc was produced from the same ore charge or the same part of the mine as the other objects in the hoard.

The major emphasis of the criticism concerning the composition of the metal objects was on the isotope

60 Gebhard, Krause 2020, [5]. analyses. ${ }^{61}$ The use of lead isotope ratios for the determination of the provenance of metals was introduced some fifty years ago, ${ }^{62}$ first for lead and silver and later also for copper-based objects. ${ }^{63}$ The advantage of the lead isotope ratios for the provenance of copper is the fact that the ore and the final object have the same isotopic composition as long as no other lead containing material was added to the copper. This can safely be assumed when the lead concentration is below c. $2 \%$, which is the case for the Nebra hoard. However, lead isotope ratios are not unique for each deposit and it is possible that an overlap can occur between the characteristics of different deposits. In that case it is advisable to use both sets of parameters, namely trace element patterns and lead isotope ratios. ${ }^{64}$

This combined approach was also used for the Nebra hoard and it turned out that the lead isotope ratios exhibit a very large spread. At first sight this would have contradicted the conclusion drawn from the chemical composition. However, it was already known that copper deposits with low lead concentrations commonly tend to contain highly variable lead isotope ratios due to the presence of uranium. This is explained in more detail elsewhere, ${ }^{65}$ but it was already known that Mitterberg is one of those copper deposits that are chemically rather homogenous but quite variable in their lead isotope ratios. This characteristic confirms the conclusion that all objects of the Nebra hoard consist of copper from the same mining region but were not cast from one large batch of homogeneous copper or bronze.

61 Gebhard, Krause 2020, [5-8].

62 Grögler et al. 1966. - Brill, Wampler 1967.

63 Gale, Stos-Gale 1982.

64 Pernicka 2014a.

65 Pernicka et al. 1993. - Pernicka 2014a. 


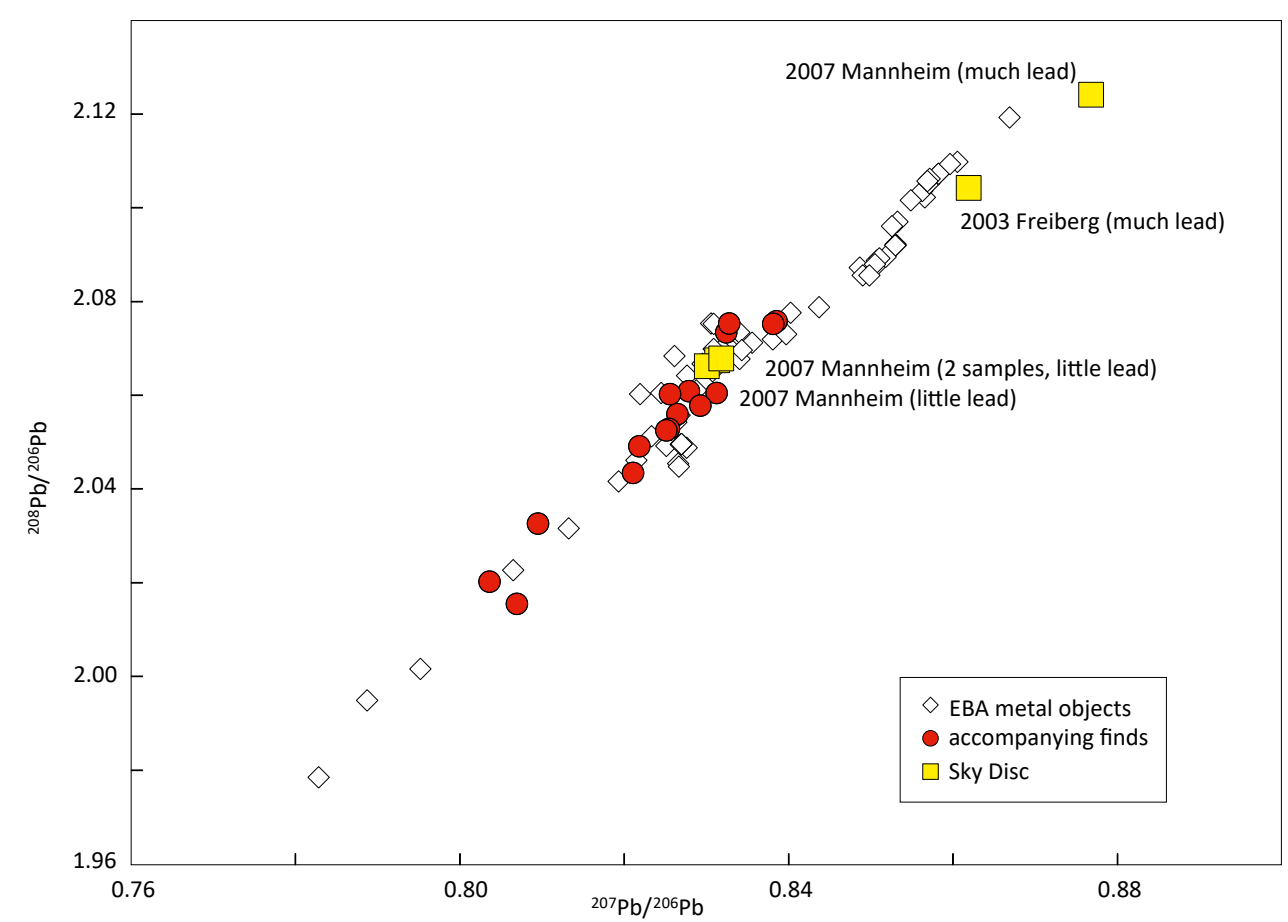

Fig. 21. Lead isotope ratios of the Nebra hoard (measurements 2003 and 2007) and Early Bronze Age metal objects from the region around Nebra (unpublished). The lead concentrations were not determined during the measurements of the lead isotope ratios but a relative estimate was accomplished by the count rates for lead (M. Brauns, CEZA Mannheim).

The lead isotope ratios of the Nebra hoard were first measured at the newly founded Institute of Archaeometallurgy at the Freiberg University of Mining and Technology, Saxony, and were included in a diploma thesis. ${ }^{66}$ The discussion of the lead isotope ratios followed a similar line as described above, namely that the large spread of values may be due to uranium- and/or thorium-bearing copper ores. It was thus concluded that "The isotopic inhomogeneity of the Nebra artefacts does not speak against a uniform metal origin. Therefore only the uniformity of the chalcophile trace element analysis and not isotopic inhomogeneity is of importance". ${ }^{67}$

A number of remaining samples were re-analysed in 2007 by Michael Brauns in the Curt-Engelhorn-Zentrum Archäometrie in Mannheim under much better laboratory conditions $^{68}$ and it turned out that the sample of the Sky Disc analysed in Freiberg was contaminated with lead and

66 Nickel 2003.

67 Nickel 2003, 79 (translated by the authors).

68 For the laboratory procedure to measure the lead isotope ratios in Freiberg, see Niederschlag et al. 2003 and in Mannheim, see NørgaArd, Pernicka, VandKilde 2019. that the original value could not be reproduced (Fig. 21). ${ }^{69}$ Fortunately, a second sample from the interior of the Sky Disc and another one from the rim contained much less lead and yielded reproducible results so that it can safely be assumed that those were not contaminated. The mean value of these two measurements was taken as the true lead isotope ratio of the Sky Disc and published in 2008 and 2010. ${ }^{70}$ These represent the final values of all objects in the Nebra hoard.

Three more objects in the Nebra hoard yielded enough remaining sample material to check if further contamination had occurred (Tab. 3). Since most values agree within errors, it can be assumed that all values for the accompanying objects are correct. Even with the wrong value for the Sky Disc included in the diploma thesis, it is not possible to state that the Sky Disc has an "exceptional position", ${ }^{71}$ if one considers other Early Bronze Age objects from the same region

69 The origin of this contamination cannot be traced, but laboratory contamination during sample preparation can be ruled out, because the remaining sample material was also contaminated. Accordingly, the contamination may have been introduced by the drill bit or the sample vial.

70 Pernicka et al. 2008, 335-337. - Pernicka 2010, 730 and Tab. 6. 71 Gebhard, Krause 2020, [7]. 


\begin{tabular}{|l|l|l|l|c|c|c|}
\hline \multicolumn{1}{|c|}{ Lab no. } & \multicolumn{1}{c|}{ Museum ID } & \multicolumn{1}{c|}{ Object } & \multicolumn{1}{c|}{ Analysis } & ${ }^{208} \mathrm{~Pb} /{ }^{206} \mathrm{~Pb}$ & ${ }^{207} \mathrm{~Pb} /{ }^{206} \mathrm{~Pb}$ & ${ }^{206} \mathrm{~Pb} /{ }^{204} \mathrm{~Pb}$ \\
\hline FG-020687 & HK 2002:1649 e & sword hilt & Mannheim 2007 & 2.0602 & 0.82557 & 19.029 \\
\hline FG-020687 & HK 2002:1649 e & sword hilt & Freiberg 2003 & 2.0609 & 0.82595 & 19.043 \\
\hline FG-020680 & HK 2002:1649 b & chisel & Mannheim 2007 & 2.0155 & 0.80692 & 19.477 \\
\hline FG-020680 & HK 2002:1649 b & chisel & Freiberg 2003 & 2.0171 & 0.80770 & 19.503 \\
\hline FG-020701 & HK 2002:1649 h & sword hilt, tang & Mannheim 2007 & 2.0491 & 0.82181 & 19.112 \\
\hline FG-020701 & HK 2002:1649 h & sword hilt, tang & Freiberg 2003 & 2.0485 & 0.82191 & 19.126 \\
\hline FG-020984 & HK 2002:1649 a & Sky Disc, drill hole 2 & Freiberg 2003 & 2.1043 & 0.86185 & 18.105 \\
\hline Avg HS2-1 & HK 2002:1649 a & Sky Disc, drill hole 2 & Mannheim 2007 & 2.1242 & 0.87675 & 17.737 \\
\hline HS 1 & HK 2002:1649 a & Sky Disc, drill hole 1 & Mannheim 2007 & 2.0662 & 0.83002 & 18.920 \\
\hline HS A & HK 2002:1649 a & Sky Disc, drill hole 1 & Mannheim 2007 & 2.0675 & 0.83126 & 18.888 \\
\hline Himmelss. & HK 2002:1649 a & Sky Disc, rim & Mannheim 2007 & 2.0679 & 0.83175 & 18.879 \\
\hline
\end{tabular}

Tab. 3. Lead isotope ratios of samples analysed in Freiberg and Mannheim.

and the fact that the Mitterberg copper deposit has highly variable lead isotope ratios.

The application of cluster analysis for this small data set is neither necessary nor methodologically correct. The methods applied (average linkage, centroid method, Ward's method) cannot identify very elongated groups because they search for multivariate globular groups, implicitly assuming a normal distribution of the values in each variable. However, lead isotope ratios are usually not normally distributed. ${ }^{72}$ Incidentally, cluster analysis is only an aid to identify structure in multivariate data that should not be correlated. However, lead isotope ratios are usually highly correlated for geochemical reasons, and anyone can see that the incorrect value of the Sky Disc has a larger distance to the data points in the centre of the diagram, but not larger than the three samples in the lower left part of the diagram (see Fig. 21). This part of the argument is therefore obsolete.

Gebhard and Krause, however, present a diagram of lead and tin isotope ratios of objects from the Nebra hoard and other Early Bronze Age objects that was recently published in an extended abstract of a conference. ${ }^{73}$ Surprisingly, it was observed that the two isotope ratios are highly correlated, which can only be explained by the remelting and mixing of bronze objects. The major goal of that study was to investigate the origin of the earliest known swords in Europe of the so-called Apa type, named after the eponymous hoard of swords in northwestern Romania. These swords are the model for the hilts of the two swords from Nebra. ${ }^{74} \mathrm{~A}$ few

\footnotetext{
72 BAXTER 1999.

73 Brügmann et al. 2018. - Gebhard, Krause 2020, [8] and Fig. 4. 74 Meller 2013, 503-515.
}

other objects from the Nebra hoard also follow this trend, so that these may also consist of mixed bronze. However, this need not necessarily be the case for all objects, especially if they might not be contemporary with the swords, like the Sky Disc, which is generally assumed to be older than the swords.

According to Gebhard and Krause this diagram confirms that the Nebra ensemble does not belong together. ${ }^{75}$ This interpretation is based on two data points, which lie off the general trend in this diagram. The original conference article, however, referred mainly to the somewhat unexpected phenomenon of bronze recycling. This could point to the sphere of action of a single workshop or a group of associated workshops that used specific bronze or ore sources and finished the objects for a limited period of time locally, for example in the Carpathian Basin. Thus, the isotopic composition of the swords from Denmark provides an argument for considering them as imported pieces from the south. Furthermore, these data show the close relationship of the sword from Valsømagle with the swords of Apa type, which formerly was only suspected based on stylistic and technical criteria as well as a similar chemical composition. ${ }^{76}$ Accordingly, outliers of this trend do not necessarily imply that they do not belong to a single archaeological context.

What is more irritating is the fact that Gebhard and Krause modified the original figure without mentioning this modification in their figure caption. For example, they labelled the outlier data points with the numbers 1 and 2 and related these to the Sky Disc (1) and a chisel (2) to illustrate

75 Gebhard, Krause 2020, [8].

76 Cf. Bunnefeld 2016, 61-63. 


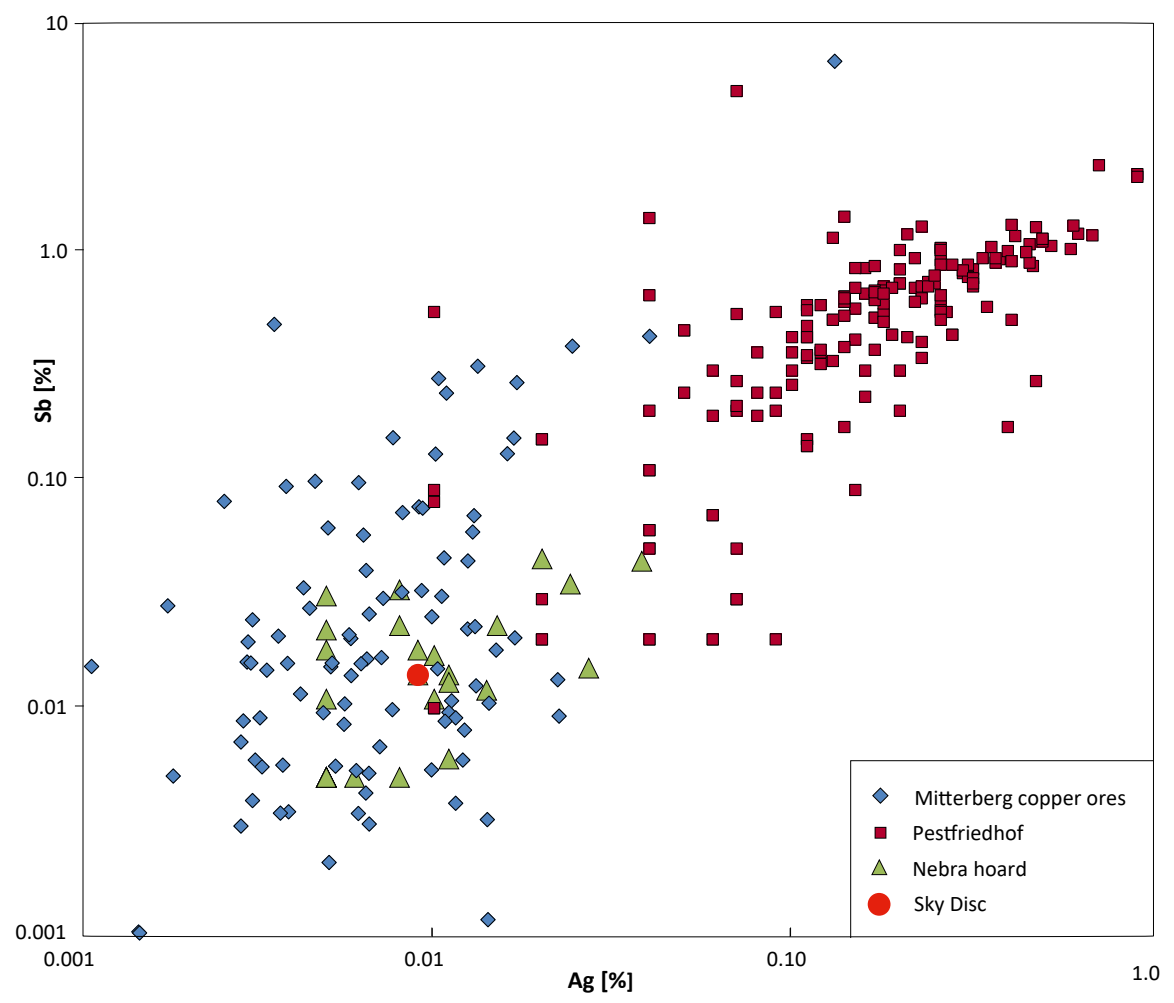

Fig. 22. Silver and antimony concentrations of copper-based metal objects from the Iron Age cemetery Bischofshofen-Pestfriedhof compared with copper ores from the Mitterberg mining region and the Nebra hoard. Copper ores were normalised against copper in order to be comparable with the artefacts. - Data for Mitterberg from Pernicka, Lutz, Stöllner 2016, data for Pestfriedhof from Northover 2009 and data for the Nebra hoard from Pernicka 2010 (E. Pernicka, CEZA Mannheim).

their interpretation. The assignment of sample 2 to the chis$\mathrm{el}$, however, is wrong and it is unclear on what information the authors based this assignment: the raw data have not yet been published, neither in the conference volume nor in any other publication. Gebhard and Krause also did not contact the authors of the original figure to ask for further information or assistance, otherwise they would have realised that the chisel was not analysed for tin isotopes at that time; thus it is not part of the data set shown in this figure. The data point is actually related to a rivet. This kind of modification of original published data is in conflict with ethical principles common across all scientific disciplines.

\subsection{Provenance of the Metals of the Nebra Hoard}

Although the provenance of the metals of the Nebra hoard is not discussed in detail by Gebhard and Krause, they nevertheless claim that the provenance of the copper from the Mitterberg area, which they do not dispute, would also be consistent with their proposed dating of the Sky Disc to the
Iron Age. ${ }^{77}$ In support of this statement they cite an article by Joachim Lutz ${ }^{78}$ that deals with the analyses of three Bronze Age helmets, which could be related to the Mitterberg mine. The only chronological statement in this article simply expresses the general knowledge that large-scale mining occurred at Mitterberg mainly in the Middle and Late Bronze Age. On the other hand, a comprehensive summary of the mining activity at Mitterberg confirmed by radiocarbon dating that mining flourished between the $16^{\text {th }}$ and $13^{\text {th }}$ centuries BC and that minor mining activities, especially at the main lode, may have phased out by the $9^{\text {th }}$ century BC. This is corroborated by almost 200 metal objects from the Iron Age cemetery Pestfriedhof in the Salzach Valley just below the Mitterberg. ${ }^{79}$ These metal objects consist of a completely different type of copper than the one that was produced in the Bronze Age in the Mitterberg mine (Fig. 22), namely

77 Gebhard, Krause 2020, [5], [11].

78 Gebhard, Krause 2020, n. 25. - Cf. Lutz 2011.

79 Northover 2009. 
so-called fahlore copper that is characterised by high antimony and silver contents. It is much more likely that the copper used for the metal objects from the cemetery originates from the Inn Valley near Brixlegg, where, indeed, Late Bronze Age and Early Iron Age copper production is well attested, ${ }^{80}$ ending around $700 \mathrm{BC}$, as evidenced by the absence of any later mining archaeological findings.

Although the composition of metal artefacts cannot be used for precise dating, there are nevertheless certain recognisable trends, like the tendency from the Late Bronze Age to the Iron Age of increasingly adding lead to bronze. This is also exemplified in the cemetery of Bischofshofen-Pestfriedhof that was in use from the Late Bronze Age to the Late Iron Age with most graves dating to the Hallstatt $\mathrm{C}$ period (c. 780 to $600 \mathrm{BC}$ ). ${ }^{81}$ Bronze was not yet heavily alloyed with lead but a substantial number of objects contain one or two percent lead, which is significantly more than what the regional copper ores in the Mitterberg region and the Inn Valley contain. Still later, in the Late Iron Age, lead becomes a major component in copper-based alloys. ${ }^{82}$

However, an iron pick from the Pestfriedhof archaeological site, corresponding with the type of Iron Age picks from the Salzach Valley (Dürrnberg type), points to more recent activities, although the metal analyses for the cemetery do not match the regional deposits (see above). It may be dated to the Hallstatt period, because it precedes the typologically early forms at the Dürnberg and overlaps with the finds from the Pestfriedhof cemetery, ${ }^{83}$ but there is no evidence of large-scale production as in previous periods, judging from the lack of Iron Age smelting sites. These would undoubtedly have to be expected when smelting the sulphidic ores such as those occurring in the eastern Alps.

The assignment of archaeological metal objects to a deposit is most convincing when archaeological evidence of mining is also available to support or invalidate the supposed origin, especially if it can be shown that the exploitation is contemporaneous with the analysed objects. This is all the more true as the production figures provide an estimate of the chance that the metal is represented in the archaeological finds. It is estimated that altogether close to

\footnotetext{
80 Goldenberg 2013. - Goldenberg, Staudt, Grutsch 2019.

81 Lippert, STADler 2009.

82 Danielisová, STRnad, Mihaljevič 2018.

83 The investigation of the pick has shown beyond any doubt that the tip of the pick, unlike the ones used in salt mining, consists of a martensitic steel structure and is therefore specifically related to the lodes of the Mitterberg: STÖllner, SchwAв 2009. - The pick therefore indicates Early Iron Age mining activities near the Salzach Valley, most likely at the Eastern Haidberg part of the main lode. But this would not match the geochemical data of the Sky Disc.
}

23,000 tonnes of copper were produced in the Mitterberg region in the Bronze Age, the bulk of it between around 1700 and 1200 BC. $^{84}$ Recent investigations show that 'Mitterberg copper' was widely distributed between the Carpathian Basin and eastern central Europe, even as far as southern Scandinavia. ${ }^{85}$ Thus, it was the most important type of copper, especially in the period between the $16^{\text {th }}$ and $13^{\text {th }}$ century BC. ${ }^{86}$

The determination of the peak operating period is confirmed by 141 items of ${ }^{14} \mathrm{C}$ data (mostly determined by the AMS method in several laboratories; state of the art 2020), and dendrochronological data are available from mines and surface operations (Fig. 23). ${ }^{87}$ According to this, the main operating period of the Mitterberg area lies in the period between the $18^{\text {th }}$ and the $9^{\text {th }}$ century BC, with an emphasis on the $15^{\text {th }}$ to $13^{\text {th }}$ centuries $\mathrm{BC}$. The conclusion is that most of the black copper went to the markets during this time.

Close examination of the geochemical data suggests yet another result for the Sky Disc of Nebra. It corresponds isotopically to the geologically older ore veins around the Salzach Valley, most likely the Buchberg lode east of the Salzach River, not the main lode. In contrast, the metals investigated from the Apa hoard are related to the geochemical pattern of the main lode at Mitterberg. ${ }^{88}$ This has a certain logic, because the areas close to the Salzach River (like Buchberg, Brander lode region) might have been used earlier (from the $19^{\text {th }} / 18^{\text {th }}$ century BC) than the area around the main lode on the Mitterberg itself at higher altitude (from the $17^{\text {th }}$ century BC onwards)..$^{89}$

The assignment of the Sky Disc to the Mitterberg area is therefore secured by mining archaeological and archaeometallurgical or geochemical methods. The main phases of mining do not provide any indication of a younger, i.e. Iron Age dating, but corroborate the evidence for a Bronze Age

84 Zschocke, Preuschen 1932. - Stöllner, Hanning, HornsChuch 2011. - T. Stöllner in: Pernicka, Lutz, Stöllner 2016.

85 Pernicka, Lutz, Stöllner 2016. - Pernicka et al. 2016. - NørgaArd, Pernicka, VANdKilde 2019.

86 The eastern Alpine region was re-investigated and characterised with improved analytical detection limits within the research focus HiMAT (The History of Mining in the Tyrol and Adjacent Areas) i.e. LuTz et al. 2010. - Gebhard and Krause do not mention the more precise results that allow the differentiation of the mined lodes from the Mitterberg district and from Kitzbühel based on lead isotope ratios and trace element patterns.

87 Stöllner 2009. - T. Stöllner in: Pernicka, Lutz, Stöllner 2016. - Pichler et al. 2018.

88 See also Pernicka, Lutz, Stöllner 2016. - Pernicka et al. 2016. 89 The dating of the earliest stages of mining near the Salzach Valley is based on AMS- ${ }^{14} \mathrm{C}$-dating and also on archaeological contexts (settlements, mining contexts) starting at Bz A2: KiENLin, STÖLlNER 2009. - Eibner 2016, 444-446 and Fig. 5. 


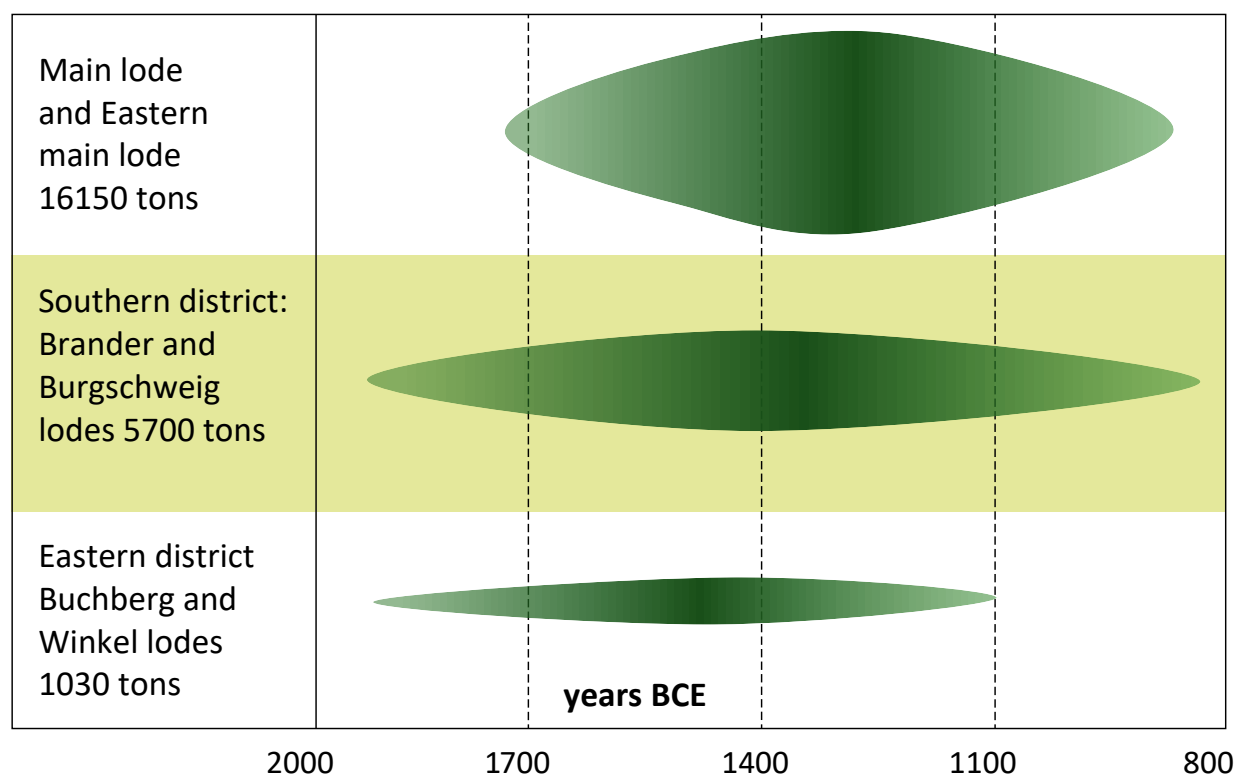

Fig. 23. Copper production in the three major ore districts in the Mitterberg region. The production was estimated from the mined averages based on the initial figures from Zschocke, Preuschen 1932 and the parameters discussed by STÖllner, Hanning, Hornschuch 2011. The losses of about $1.5 \%$ on beneficiation and $13 \%$ on smelting are based on analyses and empirical data.

date, most likely between the $18^{\text {th }}$ and $11^{\text {th }}$ centuries $\mathrm{BC}$, when the Mitterberg mine was in its main operational period. Thus, the copper of the Sky Disc can be considered as one of the very few examples for which a copper type not only ensures the authenticity but also the dating of an object.

A diachronic comparison for the gold composition comes to a similar result. Looking at Hartmann's compositional gold groups, ${ }^{90}$ one finds that his group A3 with relatively high silver concentrations and low copper contents is typical for the Early Bronze Age, whereas in the Late Bronze Age, and especially the Iron Age, copper concentrations tend to increase substantially and the silver contents tend to decrease. There is less comparative data available for the Iron Age compared to the earlier periods, but according to present knowledge, the composition of the gold of the Nebra hoard differs from that of Iron Age gold. ${ }^{91}$

Regarding the provenance studies of the gold of the Nebra Sky Disc, Gebhard and Krause ${ }^{22}$ selectively refer to and quote only initial working hypotheses ${ }^{93}$ and premature

\footnotetext{
90 Hartmann 1982.

91 Hartmann 1970.

92 Gebhard, Krause 2016. - Riederer 2016. - Gebhard, Krause 2020.

93 Pernicka et al. 2004. - Borg 2010.
}

proposals from a $\mathrm{PhD}$ thesis, ${ }^{94}$ but critically discard the matching with natural gold from Cornwall identified later on. ${ }^{95}$ Gebhard and Krause somehow disregard the publications that comprehensively explain the rationale of the origin of the Nebra gold from the Carnon River in Cornwall, and which include detailed discussions of the metallogenic reasons for the exclusion of alternative sources. ${ }^{96} \mathrm{It}$ is important to note that an antler pick, excavated from an alluvial placer mine along the Carnon River has been radiocarbon dated to 1620-1497 calBC, thus documenting placer mining in Cornwall during the late Early Bronze Age. ${ }^{97}$

\section{Archaeological and Astronomical Interpretations}

It is not unusual that hoard finds were deposited in isolation at topographically unique locations. Accordingly, it would not even be an argument against the find location of the $\mathrm{Ne}-$ bra hoard on the Mittelberg that seemingly "no indications of any activity on or use of the mountain during the $2^{\text {nd }}$ millennium BC were detected" ${ }^{98}$ In fact, this statement ignores the fact that structures and finds from several periods from

\footnotetext{
94 SCHMiderer 2009.

95 Ehser, Borg, Pernicka 2011.

96 Borg, Pernicka 2017. - Borg 2019. - Borg et al. 2019.

97 Timberlake, Hartgroves 2018.

98 Gebhard, Krause 2020, [2].
} 
the Neolithic and Bronze Age to the Iron Age were identified on the Mittelberg in the immediate surroundings of the findspot of the Sky Disc. The remains of a Late Bronze Age hoard were found only about $200 \mathrm{~m}$ north of the Iron Age oval rampart (feature 30/2003), and information on this is provided by Meller on the immediately following pages of his article cited by Gebhard and Krause. ${ }^{99}$ Furthermore, a Middle Bronze Age ornamental disc (find 15/03) from just outside the oval enclosure is known, ${ }^{100}$ as well as an Early Bronze Age and an Iron Age radiocarbon date from the eastern transecting rampart. ${ }^{101}$ All this reinforces the significance of the summit area of a hill above the river Unstrut with a wide view over the lowlands to the west and northwest. It was suggested by Wolfhard Schlosser that the importance of the site over such a long time period may be sought in its topographical situation as an outpost for astronomical observations. ${ }^{102}$ Although no proof for the Mittelberg being the find site, the visual relations given by the prominent dates of the solar year (sunset on 1 May behind the Kyffhäuser Mountain and on 21 June behind the Brocken massif) may be related to the Sky Disc, which we interpret as a memogram for certain calendar dates. As such, the horizon arcs on the disc relate to the summer solstice on 21 June and may indicate an astronomical relation to the find site and its surroundings.

Considering the composition of the hoard, it is remarkable that it is not only chemically but also from a typochronological point of view quite homogenous. This does not necessarily mean that it was produced in one workshop at the same time, because the hoard comprises diverse objects. It is, nevertheless, remarkable that all objects represent the same chronological phase $\mathrm{Bz}$ A2c of the central European Early Bronze Age. This is true for i) the swords, which represent proto-types of the classical Sögel swords of the early Middle Bronze Age (Bz B1a); ${ }^{103}$ ii) the arm spirals, which can be assigned to period $\mathrm{Bz} \mathrm{A} 2 \mathrm{c}$ by the hoard find from Luzice in Bohemia; ${ }^{104}$ iii) the chisel, which can also be dated to the period $\mathrm{Bz} \mathrm{A} 2 \mathrm{c}$ by the hoard find from Kläden due to its peculiar shape. ${ }^{105}$ It has to be considered that for the

99 Meller 2010a, particularly 42-44, 41 and Fig. 10 (finds); 39 and Fig. 8 a (plan with all Bronze Age finds). - Older Neolithic finds from the Mittelberg have also been illustrated: Meller 2010b, 68 . 100 Meller 2010a, 44 and Fig. 8.

101 Meller 2010a, 44, footn. 25. - Meller 2010b, 82 raises the possibility of an Early Bronze Age dating of the eastern transecting rampart.

102 E.g. Schlosser 2002. - Schlosser 2003. - Schlosser 2004. SCHLOSSER 2010.

103 Schwarz 2016, 483-484. - Schwarz 2020, 50.

104 SCHWARz 2016, 483.

105 SCHWARZ 2016, 484. phase $\mathrm{Bz} \mathrm{A} 2 \mathrm{c}$ only a few hoard and grave finds are available from central Germany at all, in order to allow for a compilation of a time-specific set. In addition, this would only be possible with extraordinary typochronological knowledge, which the treasure hunters and antiquities dealers hardly had at their disposal. In this respect, the hoard find has to be considered as most likely belonging together, simply from a purely archaeological and typological perspective.

In addition, the chemical analyses show that the disc and the accompanying finds were made of a type of copper which was dominant and widely distributed in the developed Early to Late Bronze Age. A certain 'lifetime' (period of use) of the disc is attested by the stratigraphic superimposition of the additions (horizon arcs, curved element, edge perforations). ${ }^{106}$ How long the successive iconographies remained in use before they were abandoned and supplemented or replaced by new features cannot, of course, be determined. However, it is legitimate to suggest a scenario ${ }^{107}$ and include additional corroborating information, such as the chronology of the exploitation of the mines at Mitterberg for the determination of the earliest possible time for the production of the Sky Disc.

As to the interpretation of the pictorial representation on the Sky Disc, there seems to be a general agreement that it reflects celestial bodies, namely the sun (or the full moon), the crescent moon, and stars. Since the stars are only visible during the night, the conclusion is that the Sky Disc is a representation of the night sky. ${ }^{108}$ It is also widely accepted that the cluster of seven stars can be interpreted as the Pleiades, which is the basis for the interpretation of the Sky Disc as a memogram and leap rule gauge for the lunar and solar years. ${ }^{109}$ Gebhard and Krause do not mention these seven stars but, citing Emília Pásztor and Carl Roslund, ${ }^{110}$ state that "the 'stars' shown on the disc [...] do not represent a concrete image of the sky". ${ }^{111}$ But in the same article it is also stated that "...one cluster of seven spots lying between the 'sun' and the 'moon' has naturally been associated with the Pleiades", 112 a statement ignored by Gebhard and Krause. The Pleiades as a star cluster are clearly separated from the otherwise evenly distributed stars. ${ }^{113}$

106 Meller 2010a, 44-48.

107 Meller 2010a, 48 and Fig. 16.

108 SCHLOSSER 2010.

109 R. Hansen 2007. - R. Hansen 2010.

110 PÁsztor, Roslund 2007.

111 Gebhard, Krause 2020, [13]. - Cf. Schlosser 2002. SCHLOSSER 2003.

112 PÁszTor, Roslund 2007, 269.

113 SChlosser 2002. - SCHLOSSER 2003. - SCHLOSSER 2004. SCHLOSSER 2010, 921-922. 
It rankles that Gebhard and Krause do not discuss the Pleiades at all because they are present on the sword blade of Allach, according to Peter Kurzmann's statement. ${ }^{114}$ But, this constellation is not depicted on the gold bowl of Zürich-Altstetten (= Ha C2-D2), ${ }^{115}$ which is dated by Gebhard and Krause to the late Urnfield period ${ }^{116}$ and thus too early. As is usual in regions of the early situla style, the iconography includes an animal frieze with deer and other animals. Above this, bosses (suns) and horizontal lunar crescents are depicted in alternating sequence, below a row of horizontal C-shaped arcs. Except for the suns, the animal figures are recessed from the finely bossed background. Only the points of the deer antlers are additionally incised with a graver. It remains open whether the decoration resembling crescent moons is really intended as such, since the crescent moon never appears horizontally but always, though slightly tilted, upright in the night sky. If the many small bosses really represent stars, as Gebhard and Krause assume, then the animals would most likely represent signs of the zodiac. The Pleiades apparently have no meaning in the Altstetten sky and are therefore missing.

In the La Tène period, only six stars of the Pleiades were visible, as the Greek astronomer Aratos of Soloi (c. 310$245 \mathrm{BC}$ ) testifies in his Phainómena (celestial phenomena): "Close to his (i.e. the constellation Perseus') left knee, all the Pleiades travel in a swarm. The place, which is not very large, holds them all, and they are only faintly visible. Seven pathways are called those among the people, although only six of them can be seen with eyes. After all, the star was not lost without news from the house of Zeus, after we heard about its creation, rather it is spoken of in exactly the same way." 117

On the 'rainbow' stater Celtic coins of the type 'Vogelkopfstater' from the $2^{\text {nd }}$ century $\mathrm{BC},{ }^{118}$ six points are depicted which are vaulted by an arch with small spherical ends. The latter is usually referred to as a torque. However, a neck ring is to be depicted as a circular shape and not as a wide open arc. If this argumentation is correct, the coins

114 KuRzmann 2016. - The reference made in connection with this sword by Gebhard, Krause 2020, [17] with n. 67 and 73 on David 2010, esp. 481-482, that the Sky Disc is an outlier in Bronze Age symbols claims David as a key witness for a possible La Tène period dating of the Sky Disc. But David only discusses this possibility in order not to pursue it in the end and is anyway convinced of the Bronze Age dating of the Nebra Sky Disc.

115 Straub 1980, 228, cat. no. 10.14. - For comparison, see Prüssing 1991, Taf. 118-119.

116 Gebhard, Krause 2020, [13]. - See also the discussion in Nagy 1992, 113, who favours a late Urnfield period date.

117 Arat. 254-261. - English translation after ERREN 1971.

118 See, e.g., the coin hoards from Gaggers and Irsching: OvERBECK 1981, 58-59 and Figs. 9-10. would actually show representations of the Pleiades, but would be set in a completely different mythological background. The arch on the coins could then be interpreted not as a torque but as the firmament. Gebhard and Krause suggest that these arcs are not torques, but they lose sight of the essential, the Nebra Sky Disc, whereby the intention of their explanations remains unclear.

The search for analogies becomes far-fetched with the reference to the Holstein belts, a costume element of the Jastorf Culture that developed in the $\mathrm{Ha}$ D2 stage, whose distribution is limited to northern Germany and never reached central Germany. The components identified by Gebhard and Krause are "serpents, arches with spherical ends, arcs with different numbers of dots below, encircled knobs with a corona (sun symbols), as well as half-arches with external dashes" ${ }^{119}$ which are not found at all on the Sky Disc in the manner presented. The reference to Paul Gleirscher's interpretation, ${ }^{120}$ who purported to be able to identify the arc as a harvest sickle, does not lead any further either, since the arc with feather-like incisions all around definitely is not a sickle.

The two authors Gebhard and Krause also remarked on "the noticeably simple craftsmanship of the "Himmelsscheibe". ${ }^{121}$ This does not match the high level of Celtic art, which is why it is considered a product of the region north of the low mountain range. There, on the edge of the Keltiké, it is held that people were not able to produce objects of high craftsmanship. In fact, the craftsmanship of the Sky Disc is indeed somewhat primitive. The Celts would have probably outlined every single star, the sun or the full moon, and the crescent moon with a compass, and also placed the stars in a firmament constructed with the compass. No construction lines can be identified on the Sky Disc. ${ }^{122}$ Also, the gold sheets were clamped at their edges into grooves cut with a chisel. In comparison, even the inlay of the Nebra swords testify to greater craftsmanship and knowledge. ${ }^{123}$ Finally, the reference to Siberian shaman drums with a decoration similar to the Sky Disc ${ }^{124}$ counteracts Gebhard and Krause's dating to the Iron Age.

As a unique find, the Nebra Sky Disc is and remains an absolutely singular specimen. It goes without saying that it

\footnotetext{
119 Gebhard, Krause 2020, [14].

120 GLEIRSCHER 2007.

121 Gebhard, Krause 2020, [14].

122 BREUER 2010 was able to plausibly demonstrate that the disc is constructed from seven circles or circle segments, which are based on a small common multiple of $26.5 \mathrm{~mm}$. This concept cannot be compared with the complex Celtic toreutics. 123 Cf. Berger 2012, 34 and Pls. 2-4. 124 Gebhard, Krause 2020, [13].
} 
therefore is not easy to fit into the motif stock of its time. Nevertheless, it is important to note that the ship in particular, which was added in phase III of the Sky Disc, ${ }^{125}$ is an element that does not appear in the Iron Age but is a central motif of the Bronze Age. ${ }^{126}$

Table 4 summarises the most important arguments and shows the most important published works. ${ }^{127}$

\section{The Judicial Assessment of the Case}

A few brief remarks shall be devoted to the judicial assessment of the case. As already mentioned several times, it is strange that Gebhard and Krause quote from the trial against robbers and dealers from the documents of the since-deceased expert Josef Riederer ${ }^{128}$ as well as from those of the criminal defence lawyer Elke Thom-Eben, ${ }^{129}$ who in turn had provided Riederer with her documents. However, the official documents that have come to light and the detailed explanations and justifications of the Regional Court of Halle are not taken into account in the explanations of the authors Gebhard and Krause. This necessarily causes irritation, especially since the Regional Court of Halle, after an intensive examination of the defence's arguments, did not follow them in its judgment, which, on appeal by the defendants, was unconditionally confirmed by the Naumburg Higher Regional Court.

In archaeological circles it is often objected that a court cannot pass judgement on an archaeological find. This is right and wrong at the same time. Only in very few exceptional cases will the court - judge and jurors - be composed in such a way that it can judge a case on the basis of its own specific knowledge - for example, if one of the jurors happens to be a 'professional'. However, this applies to any criminal trial. Even in a murder case, the judge himself does not autopsy the victim or analyse fingerprints and DNA samples. Nevertheless, the (often sworn) experts who carry out this work are required to present their methods, especially the limits of their methods, and the results of their investigations and their probability and significance to the court in an objective and truthful manner so that the court can form its own opinion on the expert's reports.

In the court trial against the antiquities dealers concerning the Nebra Sky Disc, the question of the authenticity of the find, including its origin and composition, was of fundamental importance. After extensive compilation and

125 On the phases of the Sky Disc: Meller 2010a, 44-48, 59-70.

126 Cf. Meller 2002. - Maraszek 2010. - In general Kaul 1998.

127 See also footn. 3.

128 Gebhard, Krause 2020, [18], n. 10; [19], n. 16

129 In GebHaRd, Krause 2020, [18], n. 8, the name is incorrectly given as “RA [=Rechtsanwältin] Thommen”. assessment of all pieces of evidence, the court answered this question "affirmatively with a probability close to certainty". In the light of this endeavour, the verdict of the Regional Court of Halle cannot be denied validity, even in a scientific discourse.

\section{Conclusions}

In a recently published article, Rupert Gebhard and Rüdiger Krause tried to prove that the Nebra Sky Disc should not be dated to the Early Bronze Age, as the consensus of specialists assumes, but rather to the Iron Age. The conditio sine qua non of their thesis is the assumption that the connection between the Sky Disc and the other finds of the ensemble, whose Bronze Age date the authors do not call into question, is uncertain. Thus a closed find cannot be assumed. The Sky Disc must therefore be treated as a single find and can only be dated with the help of stylistic and cultural-historical considerations.

As arguments they cite, in particular, that the location of the disc close to the surface speaks against its being found in situ, and thus its connection with the other finds is called into question. This is supported, they believe, by the nature of the traces of damage on the Sky Disc, by geochemical and forensic examinations of the soil adhesions, and by deviating descriptions of the finding by the looters. Therefore, it is even conceivable that the Sky Disc may have been found in a different location from the Mittelberg near Nebra. Incidentally, all of these arguments and assertions are, for the most part, repetitions of an earlier publication ${ }^{130}$ which does not seem to have been given much consideration among relevant specialists.

The two authors are extremely selective in their argumentation, sometimes make false claims, and ignore a large part of the extensive research results of the last 20 years on the Nebra Sky Disc and its context. All of their arguments and allegations can be readily refuted.

1. The excavations at the site named by the looters have confirmed their statements in detail, right up to the discovery of an item that was left behind during their diggings at the site (see section 2). In particular, the fact that the Sky Disc was found near the surface does not in any way speak against the location, especially since considerable erosion can be assumed on the Mittelberg. The argument that the hoard with the Sky Disc could not have come from the Mittelberg, since it otherwise only produced Iron Age finds, is, in fact, incomprehensible. The latter assertion is incorrect, but above all, the former is not mandatory.

130 Gebhard, Krause 2016, 25-43. 


\begin{tabular}{|c|c|}
\hline Topical issues & Key publications \\
\hline \multicolumn{2}{|l|}{ Unity of the find verified by: } \\
\hline $\begin{array}{l}\text { Criminal investigations, independent confessions, judicial } \\
\text { assessment }\end{array}$ & LG HaLle 2005. \\
\hline $\begin{array}{l}\text { Sediments adhering to the Sky Disc (Sp 1, certain), Sword II (Sp 2, } \\
\text { certain) and axe HK 2002:1649 c (Sp 3, possible) }\end{array}$ & Pernicka et al. 2008, 343. - AdAm 2019. \\
\hline Metal analyses (trace elements, lead isotope ratios) & Pernicka et al. 2008, 335-337. - PERnicka 2010 (original data). \\
\hline $\begin{array}{l}\text { Associated finds date to a narrow time frame (Bz A2c) and follow a } \\
\text { characteristic pattern }\end{array}$ & $\begin{array}{l}\text { S. Hansen 2010. - Meller 2010a, 48-57. - Meller 2013, 500-503. } \\
\text { - Schwarz 2016, 483-485. }\end{array}$ \\
\hline \multicolumn{2}{|l|}{$\begin{array}{l}\text { Authenticity of the Mittelberg near Nebra as the place of discovery } \\
\text { verified by: }\end{array}$} \\
\hline $\begin{array}{l}\text { Criminal investigations, independent confessions, judicial } \\
\text { assessment }\end{array}$ & LG HALLE 2005. \\
\hline $\begin{array}{l}\text { Confirmation of the looters' statements through subsequent } \\
\text { excavations by the LDA (including locating and identifying the } \\
\text { looting pit, finding the water bottle, traces from the fire brigade } \\
\text { pickaxe, increased concentrations of gold and copper within and } \\
\text { below the looting pit) }\end{array}$ & $\begin{array}{l}\text { Pernicka et al. 2008, 332-334, 342. - Meller 2010a, 35-45. - } \\
\text { Meller 2013, 496-499. }\end{array}$ \\
\hline $\begin{array}{l}\text { Soil sample from the Mittelberg (VM 1) matches with sediments } \\
\text { adhering to the Sky Disc (Sp 1, certain), Sword II (Sp 2, certain) and } \\
\text { axe HK 2002:1649 c (Sp 3, possible) }\end{array}$ & Pernicka et al. 2008, 343. - AdAm 2019. \\
\hline Cultural-historical evidence (astronomical references) & SCHLOSSER 2002. - SCHLOSSER 2004. - SCHLOSSER 2010. \\
\hline \multicolumn{2}{|l|}{ Dating to the end of the Early Bronze Age verified by: } \\
\hline $\begin{array}{l}\text { Dating by means of associated finds (stylistic, and radiocarbon date } \\
\text { from one of the swords); the multiphase character of the Sky Disc } \\
\text { suggests an earlier date of manufacture than the associated finds }\end{array}$ & $\begin{array}{l}\text { Meller 2002. - Meller 2010a. - Meller 2013. - SchWARz 2016, } \\
\text { 483-485. }\end{array}$ \\
\hline Use of copper from the Mitterberg mining district & $\begin{array}{l}\text { Pernicka et al. 2008, 335-337. - Frotzscher 2009. - Pernicka } \\
\text { 2010, 725-732. - Frotzscher 2012. - Pernicka, Lutz, Stöllner } \\
\text { 2016. }\end{array}$ \\
\hline $\begin{array}{l}\text { Main phase of use of Mitterberg copper in the Bronze Age (usage } \\
\text { probably ends in the } 9^{\text {th }} \text { century BC) }\end{array}$ & Pernicka, Lutz, Stöllner 2016. \\
\hline $\begin{array}{l}\text { Correlation of tin and lead isotope ratios of the Nebra hoard and } \\
\text { other Early Bronze Age objects }\end{array}$ & BRÜGMANN et al. 2018. \\
\hline $\begin{array}{l}\text { Cultural-historical evidence (representation of a ship on the Sky } \\
\text { Disc as a central motif of the Bronze Age, relatively primitive } \\
\text { technical production and motifs of the Sky Disc speak against Celtic } \\
\text { craftsmanship) }\end{array}$ & Meller 2002. - David 2010, 481-482. - Maraszek 2010. \\
\hline $\begin{array}{l}\text { Origin of the gold on the Sky Disc and the swords from the Carnon } \\
\text { River in Cornwall; gold from this source was already extracted in } \\
\text { the Early Bronze Age }\end{array}$ & $\begin{array}{l}\text { Ehser, Borg, Pernicka 2011. - Borg, Pernicka 2017. - } \\
\text { Timberlake, Hartgroves 2018. - Borg 2019. - Borg et al. } 2019 .\end{array}$ \\
\hline \multicolumn{2}{|l|}{ Further investigations: } \\
\hline Damage to the Sky Disc & Pernicka, Wunderlich 2002, 30. - Pernicka et al. 2008, 339-342. \\
\hline Corrosion on the Sky Disc & Pernicka, Wunderlich 2002, 24. - Pernicka et al. 2008, 337-339. \\
\hline $\begin{array}{l}\text { Further Neolithic, Middle and Late Bronze Age finds from the } \\
\text { Mittelberg }\end{array}$ & $\begin{array}{l}\text { Meller 2010a, } 41 \text { and Fig. 10; 43-44. - Meller 2010b, 66-70 } \\
\text { (selection). }\end{array}$ \\
\hline Pedological investigations on the Mittelberg and its surroundings & Klatt, Stelter 2019. \\
\hline
\end{tabular}

Tab. 4. A large number of investigations prove the unity of the hoard, the authenticity of the location, and the dating of the Sky Disc to the end of the Early Bronze Age. The table shows the investigations carried out as well as the most important published works. Highlighted in blue are references which were only selectively or falsely considered by GeBHARD, Krause 2020, in red, publications that were not considered. 
2. The investigation of the damage to the Sky Disc shows beyond doubt that this did not occur on different occasions that were far apart in time, but most likely during the process of its improper recovery by the looters (see section 3 ). The assertion that the soil samples from the site and the sediments adhering to the found objects would show that the accompanying finds and the Sky Disc did not come from the same site is wrong. On the contrary, the samples from the looter's pit and the soil adhering to the Sky Disc and one of the splendid swords revealed the greatest possible accordance (see section 4). Just as false is the claim that one of the bronze axes did not belong to the hoard according to the forensic expert. In this case, the samples were not sufficient to make a definite statement, but based on the forensic investigations, the affiliation is at least possible. The affiliation of the sword and the Sky Disc alone is sufficient for an archaeological-temporal classification.

3. The assertion that the geochemical analyses do not support the integrity of the hoard is also incorrect. Analyses show that for the Nebra bronze finds copper from the Mitterberg district in the Salzburg Alps had been employed which was no longer being used during the Iron Age. Moreover, when compared to each other, Iron Age and Bronze Age copper alloys show completely different composition patterns, both in terms of their main components as well as the trace elements and lead isotope ratios (see section 4).

Since the basis for a re-dating to the Iron Age thus no longer applies - and it can hardly be assumed that the swords, which were almost as good as new, were deposited more than a thousand years after their manufacture - also the further arguments put forward by Gebhard and Krause are largely obsolete. Especially as the Celtic comparative examples they cite belong formally, stylistically, and cultural-historically to a completely different context (see section 5).

Due to the fact that the Nebra hoard was not recovered in a scientifically controlled excavation and without any photographic documentation, it is only natural that doubts arise. This led to unprecedented scrutiny of the evidence available not only in the court trial but also in a number of scientific investigations on the Nebra Sky Disc and its surroundings, in order to put the findings to the test again, and, if necessary, to modify, revise or confirm earlier conclusions. Without sceptical remarks, some lines of investigation might not have been followed at all. The investigations will continue. For the near future, a compilation of all relevant, often scattered publications - including the research results not yet published - is planned, as well as a catalogue-like presentation of the Nebra finds. This will not only shed further light on this important find but will also provide new impulses to Bronze Age research as a whole. In particular, the research around the Nebra hoard find can be considered as an outstanding example of the fruitful cooperation of numerous disciplines from the natural sciences and the humanities.

\section{References}

ADAM 1984

J. ADAM, Boden und Staubspuren: Suche/Sicherung/Analyse. Berlin 1984.

ADAM 2019

J. ADAM, Kriminaltechnische Untersuchung der Erdanhaftungen an der Himmelsscheibe. In: H. Meller, F. Bertemes (Eds.), Der Aufbruch zu neuen Horizonten: Neue Sichtweisen zur europäischen Frühbronzezeit. Abschlusstagung der Forschergruppe FOR550 vom 26. bis 29. November 2010 in Halle (Saale). Tagungen des Landesmuseums für Vorgeschichte Halle 19, Halle (Saale) 2019, 87-92.

BAXTER 1999

M. J. BAXTER, On the multivariate normality of data arising from lead isotope fields, Journal of Archaeological Science 26, 1999, $117-124$.

BERGER 2012

D. Berger, Bronzezeitliche Färbetechniken an Metallobjekten nördlich der Alpen: Eine archäometallurgische Studie zur prähistorischen Anwendung von Tauschierung und Patinierung anhand von Artefakten und Experimenten. Forschungsberichte des Landesmuseums für Vorgeschichte Halle 2, Halle (Saale) 2012.

BerTEMEs 2019

F. Bertemes, Der Aufbruch zu neuen Horizonten - Die Funde von Nebra, Sachsen-Anhalt, und ihre Bedeutung für die Bronzezeit Europas: Die DFG-Forschergruppe FOR550. In: H. Meller, F. Bertemes (Eds.), Der Aufbruch zu neuen Horizonten: Neue Sichtweisen zur europäischen Frühbronzezeit. Abschlusstagung der Forschergruppe FOR550 vom 26. bis 29. November 2010 in Halle (Saale). Tagungen des Landesmuseums für Vorgeschichte Halle 19, Halle (Saale) 2019, 21-32.

Borg 2005

G. Borg, Röntgendiffraktometrische Phasenbestimmung (Mineralbestimmung) der Tonfraktion von Anhaftungen an Gegenständen des Fundes von Nebra sowie von Sedimentmaterial vom Mittelberg bei Nebra. Unpublished report, 18.02.2005, 3 p.

BORG 2010

G. Borg, Warum in die Ferne schweifen? Geochemische Fakten und geologische Forschungsansätze zu Europas Goldvorkommen und zur Herkunft des Nebra-Goldes. In: H. Melder, F. BerTeMEs (Eds.), Der Griff nach den Sternen: Wie Europas Eliten zu Macht und Reichtum kamen. Internationales Symposium in Halle (Saale), 16.-21. Februar 2005. Tagungen des Landesmuseums für Vorgeschichte Halle 5, Halle (Saale) 2010, 735-749.

BORG 2019

G. BORG, In search of the golden sky - Cornwall as the source of the gold of the Bronze Age Sky Disc of Nebra, Journal of the Royal Institution of Cornwall, 2019, 38-57.

Borg, Pernicka 2017

G. Borg, E. Pernicka, Goldene Zeiten? - Europäische Goldvorkommen und ihr Bezug zur Himmelsscheibe von Nebra, Jahresschrift für Mitteldeutsche Vorgeschichte 96, 2017, 111138. 
Borg, Pöllmann, Stöber in prep.

G. Borg, H. PÖllmanN, S. STÖBER, Vergleichende röntgendiffraktometrische (XRD) Untersuchungen von Sedimentanhaftungen des Hortfundes der Himmelsscheibe von Nebra sowie einer Sedimentprobe vom Mittelberg im südlichen Sachsen-Anhalt. In: H. Meller (Ed.), Die Himmelsscheibe von Nebra. Forschungsberichte des Landesmuseums für Vorgeschichte Halle, in preparation.

Borg et al. 2019

G. Borg, E. Pernicka, A. Ehser, N. Lockhoff, G. S. Camm, C. V. SMALE, From distant lands - provenance studies of natural gold in comparison to the gold of the Sky Disc of Nebra. In: H. Meller, F. Bertemes (Eds.), Der Aufbruch zu neuen Horizonten: Neue Sichtweisen zur europäischen Frühbronzezeit. Abschlusstagung der Forschergruppe FOR550 vom 26. bis 29. November 2010 in Halle (Saale). Tagungen des Landesmuseums für Vorgeschichte Halle 19, Halle (Saale) 2019, 55-78.

BREUER 2010

H. BREuer, Untersuchungen der Maßverhältnisse der Himmelsscheibe von Nebra. In: H. Meller, F. Bertemes (Eds.), Der Griff nach den Sternen: Wie Europas Eliten zu Macht und Reichtum kamen. Internationales Symposium in Halle (Saale), 16.-21. Februar 2005. Tagungen des Landesmuseums für Vorgeschichte Halle 5, Halle (Saale) 2010, 91-96.

BriLl, WAMPLER 1967

R. H. BRILL, J. M. WAMPLER, Isotope ratios in archaeological objects of lead. In: Boston Museum of Fine Arts (Ed.), Application of Science in Examination of Works of Art. Proceedings of the Seminar, September 7-16, 1965. Boston 1967, 155-166.

BRÜGMANN et al. 2018

G. Brügmann, D. Berger, B. Nessel, E. Pernicka, Chemische Zusammensetzung und Zinn- und Bleiisotopenverhältnisse in Schwertern des Typs „Аpa“ und assoziierten Bronzeobjekten aus Apa, Nebra und Dänemark. In: L. Glaser (Ed.), Archäometrie und Denkmalpflege 2018. 20.-24. März 2018, DESY, Hamburg. Hamburg 2018, 64-67.

BuNNEFELD 2016

J.-H. Bunnefeld, Älterbronzezeitliche Vollgriffschwerter in Dänemark und Schleswig-Holstein: Studien zu Form, Verzierung, Technik und Funktion. Studien zur nordeuropäischen Bronzezeit 3, Kiel 2016.

Danielisová, Strnad, Mihaljevič 2018

A. Danielisové, L. Strnad, M. Mihaljevič, Circulation patterns of copper-based alloys in the Late Iron Age oppidum of Třísov in central Europe, Metalla 24/1, 2018, 5-18.

DAvid 2010

W. DAvid, Die Zeichen auf der Scheibe von Nebra und das altbronzezeitliche Symbolgut des Mitteldonau-Karpatenraumes. In: H. Meller, F. Bertemes (Eds.), Der Griff nach den Sternen: Wie Europas Eliten zu Macht und Reichtum kamen. Internationales Symposium in Halle (Saale), 16.-21. Februar 2005. Tagungen des Landesmuseums für Vorgeschichte Halle 5, Halle (Saale) 2010, 439-486.

Demmelmeyer, AdAm 1995

H. Demmelmeyer, J. Adam, Forensic investigation of soil and vegetable materials, Forensic Science Review 7, 1995, 119-142.

Ehser, Borg, Pernicka 2011

A. Ehser, G. Borg, E. Pernicka, Provenance of the gold of the Early Bronze Age Nebra Sky Disk, central Germany: geochemical characterization of natural gold from Cornwall, European Journal of Mineralogy 23/6, 2011, 895-910.

EIBNER 2016

C. Eibner, Ost und West, West und Ost, Mobilität und Technologietransfer. In: M. Bartelheim, B. Horejs, R. Krauss (Eds.), Von Baden bis Troia: Ressourcennutzung, Metallurgie und Wissenstransfer. Eine Jubiläumsschrift für Ernst Pernicka. Oriental and European Archaeology 3, Rahden/Westf. 2016, 439-451.

ERNÉE 2017

M. ERNÉE, Odstrašující případ Bernstorf aneb učebnicový příklad toho, jak nesmí vypadat spolupráceprofesionálů samatéry [The deterrent case of Bernstorf or a textbook example of how cooperation between experts should not be], Památky Archaeologické 108, 2017, 298-303.

ERREN 1971

M. Erren (Ed.), Aratos, Phainomena: Sternbilder und Wetterzeichen. Griechisch - Deutsch. Tusculum-Bücherei, Munich 1971.

Evans 1926

U. R. Evans, The Corrosion of Metals. London 1926.

FROTZSCHER 2009

M. Frotzscher, Geochemische Charakterisierung von mitteleuropäischen Kupfervorkommen zur Herkunftsbestimmung des Kupfers der Himmelsscheibe von Nebra. Dissertation, Martin Luther University Halle-Wittenberg. Halle (Saale) 2009.

Frotzscher 2012

M. Frotzscher, Geochemische Charakterisierung von mitteleuropäischen Kupfervorkommen zur Herkunftsbestimmung des Kupfers der Himmelsscheibe von Nebra. Forschungsberichte des Landesmuseums für Vorgeschichte Halle 1, Halle (Saale) 2012.

Gale, Stos-Gale 1982

N. H. Gale, Z. A. Stos-Gale, Bronze Age copper sources in the Mediterranean, Science 216, 1982, 11-19.

Gebhard, Krause 2016

R. Gebhard, R. Krause (Eds.), Bernstorf: Archäologisch-naturwissenschaftliche Analysen der Gold- und Bernsteinfunde vom Bernstorfer Berg bei Kranzberg, Oberbayern. Bernstorf-Forschungen 1, Abhandlungen und Bestandskataloge der Archäologischen Staatssammlung 3, Frankfurter Archäologische Schriften 31, Munich 2016.

Gebhard, Krause 2020

R. Gebhard, R. Krause, Critical comments on the find complex of the so-called Nebra Sky Disk, Archäologische Informationen 43, Early View, published online 3. Sept. 2020, [1-22]. [Published in German in the same journal under the title: Kritische Anmerkungen zum Fundkomplex der sog. Himmelsscheibe von Nebra].

GLEIRSCHER 2007

P. Gleirscher, Zum Bildprogramm der Himmelsscheibe von Nebra: Schiff oder Sichel? Germania 85, 2007, 23-33.

Goldenberg 2013

G. Goldenberg, Prähistorischer Fahlerzbergbau im Unterinntal - Montanarchäologische Befunde. In: K. OegGL, V. Schaffer (Eds.), Cuprum Tyrolense - 5550 Jahre Bergbau und Kupferverhüttung in Tirol. Reith i. A. 2013, 89-122.

Goldenberg, Staudt, Grutsch 2019

G. Goldenberg, M. Staudt, C. Grutsch, Montanarchaologische Forschungen zur frühen Kupferproduktion in Nordtirol - Forschungsfragen, Forschungskonzepte und Ergebnisse. In: S. HyE, U. TöchterLe (Eds.), UPIKU:TAUKE. Festschrift für Gerhard Tomedi zum 65. Geburtstag. Universitätsforschungen zur Prähistorischen Archäologie 339, Bonn 2019, 159-178. 
GRÖGLER et al. 1966

N. Grögler, J. Geiss, M. Grünenfelder, F. G. Houtermans, Isotopenuntersuchungen zur Bestimmung der Herkunft römischer Bleirohre und Bleibarren, Zeitschrift für Naturforschung 21a, 1966, 1167-1172.

R. HANSEN 2007

R. Hansen, Die Himmelsscheibe von Nebra - neu interpretiert: Sonne oder Mond? Wie der Mensch der Bronzezeit mit Hilfe der Himmelsscheibe Sonnen- und Mondkalender ausgleichen konnte, Archäologie in Sachsen-Anhalt 4/2/2006, 2007, 289-304.

R. Hansen 2010

R. Hansen, Sonne oder Mond? Verewigtes Wissen aus der Ferne. In: H. Meller, F. Bertemes (Eds.), Der Griff nach den Sternen: Wie Europas Eliten zu Macht und Reichtum kamen. Internationales Symposium in Halle (Saale), 16.-21. Februar 2005. Tagungen des Landesmuseums für Vorgeschichte Halle 5, Halle (Saale) 2010, 953-962.

S. HANSEN 2010

S. Hansen, Der Hort von Nebra: seine Ausstattung. In: H. Meller, F. Bertemes (Eds.), Der Griff nach den Sternen: Wie Europas Eliten zu Macht und Reichtum kamen. Internationales Symposium in Halle (Saale), 16.-21. Februar 2005. Tagungen des Landesmuseums für Vorgeschichte Halle 5, Halle (Saale) 2010, 77-90.

Harding, Hughes-Brock 2017

A. Harding, H. Hughes-Brock, Review article: Mycenaeans in Bavaria? Amber and gold from the Bronze Age site of Bernstorf, Antiquity 91/359, 2017, 1382-1385.

HaRTMANN 1970

A. Hartmann, Prähistorische Goldfunde aus Europa: Spektralanalytische Untersuchungen und deren Auswertung. Studien zu den Anfängen der Metallurgie 3, Berlin 1970.

HARTMANN 1982

A. Hartmann, Prähistorische Goldfunde aus Europa II. Studien zu den Anfängen der Metallurgie 5, Berlin 1982.

Hellmann et al. 2012

A. Hellmann, M. Heinz, D. Inhülsen, M. Münch, B. Olbert, U. Schlesinger, K. Schneider, G. Sommer, U. Zirpel, Die Untersuchung von Bodenspuren: Ausarbeitung eines gemeinsamen Konzeptes zur vergleichenden Bodenuntersuchung in Ermittlungs- und Strafverfahren in Deutschland, Kriminalistik 66/3, 2012, 157-161.

JUNG 2017

R. Jung, Review of R. Gebhard, R. Krause (Eds.), Bernstorf: Archäologisch-naturwissenschaftliche Analysen der Gold- und Bernsteinfunde vom Bernstorfer Berg bei Kranzberg, Oberbayern, Munich 2016, Archaeologia Austriaca 101, 2017, 333-348.

KaINZ, KLAMM in prep.

W. Kainz, M. Klamm, Geologische und bodenkundliche Verhältnisse im Bereich des Fundortes der Himmelsscheibe auf dem Mittelberg im Ziegelrodaer Forst, Saale- und Burgenlandkreis, sowie in dessen Umfeld. In: H. Meller (Ed.), Die Himmelsscheibe von Nebra. Forschungsberichte des Landesmuseums für Vorgeschichte Halle, in preparation.

KAUL 1998

F. Kaul, Ships on Bronzes: A Study in Bronze Age Religion and Iconography: Text. Publications from the National Museum, Studies in Archaeology and History 3/1, Copenhagen 1998.

KIENLIN, STÖLLNER 2009

T. Kienlin, T. Stöllner, Singen copper, Alpine settlement and Early Bronze Age mining: is there a need for elites and strongholds? In: T. Kienlin, B. Roberts (Eds.), Metals and Societies. Studies in Honour of Barbara S. Ottaway. Universitätsforschungen zur Prähistorischen Archäologie 169, Bonn 2009, 67-104.

Klatt, STElTER 2019

S. Klatt, S. Stelter, Geologisch-naturräumliche Kartierungen im Raum Kleinwangen - Ziegelrodaer Forst - Schacht Wendelstein (Blätter 4735 Nebra und 4734 Wiehe/Ziegelroda, SachsenAnhalt). In: H. Meller, G. Borg (Eds.), Im Dialog mit der Erde - Geologische Begleitforschung im Umfeld der Himmelsscheibe von Nebra. Forschungsberichte des Landesmuseums für Vorgeschichte Halle 13, Halle (Saale) 2019, 55-119.

KOIKI 2006

T. KoIKI, Überblick über die Ergebnisse der archäologischen Ausgrabungen der Jahre 2002-2004 auf dem Mittelberg im Ziegelrodaer Forst bei Nebra. Unpublished excavation report, Halle (Saale) 2006.

KuRZMANn 2016

P. Kurzmann, Die Plejaden in Gold auf einem keltischen Schwert, Archäologische Informationen 39, 2016, 239-246.

LG Halle 2005

LANDGERICHT Halle, Urteil der 10. Strafkammer des Landgerichts Halle vom 26.09.2005. Aktenzeichen 26 Ns 33/2004.

LIPPERT, STADLER 2009

A. Lippert, P. Stadler (Eds.), Das spätbronze- und früheisenzeitliche Gräberfeld von Bischofshofen-Pestfriedhof, Teil 1: Bearbeitung und Auswertung. Universitätsforschungen zur Prähistorischen Archäologie 168, Bonn 2009.

LUTZ 2011

J. Lutz, Materialanalytische Untersuchungen an den Helmen vom Pass Lueg, Anlauftal und Moosbruckschrofen. In: W. K. Kovacsovics, R. Kastler, P. Laub (Eds.), Die zweischaligen ostalpinen Kammhelme und verwandte Helmformen der späten Bronze- und frühen Eisenzeit. Archäologie in Salzburg 6, Salzburg 2011, 113-117.

LuTz et al. 2010

J. Lutz, E. Pernicka, R. Pils, G. Tomedi, F. Vavtar, Geochemical Characteristics of Copper Ores from the Greywacke Zone in the Austrian Alps and their Relevance as a Source of Copper in Prehistoric Times. In: P. Anreiter, G. Goldenberg, K. Hanke, R. Krause, W. Leitner, F. Mathis, K. Nicolussi, K. Oeggl, E. Pernicka, M. Prast, J. Schibler, I. Schneider, H. Stadler, T. Stöllner, G. Tomedi, P. Tropper (Eds.), Mining in European History and its Impact on Environment and Human Societies. Proceedings of the $1^{\text {st }}$ Mining in European History-Conference of the SFB-HiMAT, 12.-15. November 2009, Innsbruck. Innsbruck 2010, 145-150.

MaraszeK 2010

R. Maraszek, Ein Schiff auf dem Himmelsozean - Zur Deutung des gefiederten Goldbogens auf der Himmelsscheibe von Nebra. In: H. Meller, F. Bertemes (Eds.), Der Griff nach den Sternen: Wie Europas Eliten zu Macht und Reichtum kamen. Internationales Symposium in Halle (Saale), 16.-21. Februar 2005. Tagungen des Landesmuseums für Vorgeschichte Halle 5, Halle (Saale) 2010, 487-500.

MeLler 2002

H. Meller, Die Himmelsscheibe von Nebra - ein frühbronzezeitlicher Fund von außergewöhnlicher Bedeutung, Archäologie in Sachsen-Anhalt N. F. 1, 2002, 7-20.

Meller 2010a

H. Meller, Nebra: Vom Logos zum Mythos - Biographie eines Himmelsbildes. In: H. Meller, F. Bertemes (Eds.), Der Griff nach den Sternen: Wie Europas Eliten zu Macht und Reichtum 
kamen. Internationales Symposium in Halle (Saale), 16.-21. Februar 2005. Tagungen des Landesmuseums für Vorgeschichte Halle 5, Halle (Saale) 2010, 23-73.

Meller 2010b

H. Meller (Ed.), Arche Nebra - die Himmelsscheibe erleben. Kleine Reihe zu den Himmelswegen 3, Halle (Saale) 2010.

MELLer 2011

H. MeLLer (Ed.), Bronzerausch: Spätneolithikum und Frühbronzezeit. Begleithefte zur Dauerausstellung im Landesmuseum für Vorgeschichte Halle 4, Halle (Saale) 2011.

MeLler 2013

H. Meller, Der Hortfund von Nebra im Spiegel frühbronzezeitlicher Deponierungssitten. In: H. Meller, F. Bertemes, H.-R. BoRK, R. RIsch (Eds.), 1600 - Kultureller Umbruch im Schatten des Thera-Ausbruchs? / 1600 - Cultural change in the shadow of the Thera-Eruption? 4. Mitteldeutscher Archäologentag vom 14. bis 16. Oktober 2011 in Halle (Saale). Tagungen des Landesmuseums für Vorgeschichte Halle 9, Halle (Saale) 2013, 493-526.

Meller 2014

H. Meller, Die neolithischen und bronzezeitlichen Goldfunde Mitteldeutschlands: Eine Übersicht. In: H. Meller, R. Risch, E. Pernicka (Eds.), Metalle der Macht - Frühes Gold und Silber. 6. Mitteldeutscher Archäologentag vom 17. bis 19. Oktober 2013 in Halle (Saale). Tagungen des Landesmuseums für Vorgeschichte Halle 11, Halle (Saale) 2014, 611-716.

Meller, Bertemes 2019

H. Meller, F. Bertemes (Eds.), Der Aufbruch zu neuen Horizonten: Neue Sichtweisen zur europäischen Frühbronzezeit. Abschlusstagung der Forschergruppe FOR550 vom 26. bis 29. November 2010 in Halle (Saale). Tagungen des Landesmuseums für Vorgeschichte Halle 19, Halle (Saale) 2019.

Meller, Michel 2018

H. Meller, K. Michel, Die Himmelsscheibe von Nebra: Der Schlüssel zu einer untergegangenen Kultur im Herzen Europas. Berlin 2018.

Murray, Tedrow 1992

R. C. Murray, J. C. F. Tedrow, Forensic Geology. New Brunswick 1992.

NAGY 1992

P. NAGY, Technologische Aspekte der Goldschale von Zürich-Altstetten, Jahrbuch der Schweizerischen Gesellschaft für Ur- und Frühgeschichte 75, 1992, 101-116.

NicKel 2003

D. Nickel, Archäometrische Untersuchungen zum Hortfund von Nebra. Diploma Thesis, TU Bergakademie Freiberg, Freiberg 2003.

Niederschlag et al. 2003

E. Niederschlag, E. Pernicka, T. Seifert, M. Bartelheim, Determination of lead isotope ratios by multiple collector ICP-MS: a case study of Early Bronze Age artefacts and their possible relation with ore deposits of the Erzgebirge, Archaeometry 45, 2003, 61-100.

Nørgaard, Pernicka, Vandkilde 2019

H. W. Nørgaard, E. Pernicka, H. Vandkilde, On the trail of Scandinavia's early metallurgy: provenance, transfer and mixing, PLoS ONE 14/7, e0219574. doi: 10.1371/ journal.pone.0219574.

NORTHOVER 2009

P. Northover, Analysis and metallography of copper alloy metalwork. In: A. Lippert, P. StAdler (Eds.), Das spätbronze- und früheisenzeitliche Gräberfeld von Bischofshofen-Pestfriedhof,
Teil 1: Bearbeitung und Auswertung. Universitätsforschungen zur Prähistorischen Archäologie 168, Bonn 2009, 351-384.

OvERBECK 1981

B. Overbeck, Münzen der Kelten (Exhibition catalogue, Staatliche Münzsammlung München, Westfälisches Museum für Archäologie Münster). Münster 1981.

PÁsztor, Roslund 2007

E. PÁsztor, C. Roslund, An interpretation of the Nebra Disc, Antiquity $81 / 312,2007,267-278$.

Pernicka 2010

E. Pernicka, Archäometallurgische Untersuchungen am und zum Hortfund von Nebra. In: H. Meller, F. Bertemes (Eds.), Der Griff nach den Sternen: Wie Europas Eliten zu Macht und Reichtum kamen. Internationales Symposium in Halle (Saale), 16.-21. Februar 2005. Tagungen des Landesmuseums für Vorgeschichte Halle 5, Halle (Saale) 2010, 719-734.

Pernicka 2014a

E. Pernicka, Provenance determination of archaeological metal objects. In: B. W. Roberts, C. Thornton (Eds.), Archaeometallurgy in Global Perspective: Methods and Syntheses. New York 2014, 239-268.

Pernicka 2014b

E. Pernicka, Zur Frage der Echtheit der Bernstorfer Goldfunde. In: H. Meller, R. Risch, E. Pernicka (Eds.), Metalle der Macht - Frühes Gold und Silber. 6. Mitteldeutscher Archäologentag vom 17. bis 19. Oktober 2013 in Halle (Saale). Tagungen des Landesmuseums für Vorgeschichte Halle 11, Halle (Saale) 2014, 247-256.

Pernicka, Wunderlich 2002

E. Pernicka, C.-H. Wunderlich, Naturwissenschaftliche Untersuchungen an den Funden von Nebra, Archäologie in SachsenAnhalt N. F. 1, 2002, 24-31.

Pernicka, Wunderlich 2017

E. Pernicka, C.-H. Wunderlich, Review of R. Gebhard, R. Krause (Eds.), Bernstorf: Archäologisch-naturwissenschaftliche Analysen der Gold- und Bernsteinfunde vom Bernstorfer Berg bei Kranzberg, Oberbayern, Munich 2016, Prähistorische Zeitschrift 92/2, 2017, 428-444.

Pernicka, Lutz, Stöllner 2016

E. Pernicka, J. Lutz, T. Stöllner, Bronze Age copper production at Mitterberg, Austria, and its Distribution, Archaeologia Austriaca 100, 2016, 19-55.

Pernicka et al. 1993

E. Pernicka, F. Begemann, S. Schmitt-Strecker, G. A. Wagner, Eneolithic and Early Bronze Age copper artefacts from the Balkans and their relation to Serbian copper ores, Prähistorische Zeitschrift 68, 1993, 1-54.

Pernicka et al. 2004

E. Pernicka, M. Radtke, H. Riesemeier, C.-H. Wunderlich, European network of competence at 1600 BC. In: BESSY-Highlights 2003. Berlin 2004, 8-9.

Pernicka et al. 2008

E. Pernicka, C.-H. Wunderlich, A. Reichenberger, H. Meller, G. Borg, Zur Echtheit der Himmelsscheibe von Nebra - Eine kurze Zusammenfassung der durchgeführten Untersuchungen, Archäologisches Korrespondenzblatt 38, 2008, 331-352.

Pernicka et al. 2016

E. Pernicka, B. Nessel, M. Mehofer, E. Safta, Lead isotope analyses of metal objects from the Apa Hoard and other Early and Middle Bronze Age items from Romania, Archaeologia Austriaca 100, 2016, 57-86. 
Pichler et al. 2018

T. Pichler, K. Nicolussi, J. Schröder, T. Stöllner, P. Thomas, A. Thurner, Tree-ring analyses on Bronze Age mining timber from the Mitterberg Main Lode, Austria - did the miners lack wood? Journal of Archaeological Science: Reports 19, 2018, 701-711.

PitTioni 1957

R. PitTioni, Urzeitlicher Bergbau auf Kupfererz und Spurenanalyse: Beiträge zum Problem der Relation Lagerstätte - Fertigobjekt. Archaeologia Austriaca, Beiheft 1, Vienna 1957.

Prüssing 1991

G. Prüssing, Die Bronzegefäße in Österreich. Prähistorische Bronzefunde II/5, Stuttgart 1991.

REICHENBERgER 2017

A. Reichenberger, Review of R. Gebhard, R. Krause (Eds.), Bernstorf: Archäologisch-naturwissenschaftliche Analysen der Gold- und Bernsteinfunde vom Bernstorfer Berg bei Kranzberg, Oberbayern, Munich 2016, Jahresschrift für Mitteldeutsche Vorgeschichte 96, 2017, 543-550.

RENNER [2005]

M. RenNer, Der Sensationsfund von Nebra: Eine anhaltinische Schatzgräberlegende: Fiktiver Bericht, aufgeschrieben von Kathrin Aehnlich und Steffen Lüddemann. Leipzig [2005].

RIEDERER 2016

J. Riederer, Stellungnahme vom Februar 2005 zur Scheibe aus der Bronzezeit. In: R. Gebhard, R. Krause (Eds.), Bernstorf: Archäologisch-naturwissenschaftliche Analysen der Gold- und Bernsteinfunde vom Bernstorfer Berg bei Kranzberg, Oberbayern. Bernstorf-Forschungen 1, Abhandlungen und Bestandskataloge der Archäologischen Staatssammlung 3, Frankfurter Archäologische Schriften 31, Munich 2016, 307-319.

SCHAUER 2005a

P. SCHAUER, Kritische Anmerkungen zum Bronzeensemble mit "Himmelsscheibe“ angeblich vom Mittelberg bei Nebra, Sachsen-Anhalt, Archäologisches Korrespondenzblatt 35, 2005, 323-328.

SCHAUER $2005 \mathrm{~b}$

P. Schauer, Korrektur zum Beitrag: Kritische Anmerkungen zum Bronzeensemble mit „Himmelsscheibe“ angeblich vom Mittelberg bei Nebra, Sachsen-Anhalt, Archäologisches Korrespondenzblatt 35, 2005, 559 .

SCHLOSSER 2002

W. Schlosser, Zur astronomischen Deutung der Himmelsscheibe von Nebra, Archäologie in Sachsen-Anhalt N. F. 1, 2002, 21-23.

SCHLOSSER 2003

W. Schlosser, Astronomischen Deutung der Himmelsscheibe von Nebra, Sterne und Weltraum 12, 2003, 34-40.

SCHLOSSER 2004

W. Schlosser, Die Himmelsscheibe von Nebra - Astronomische Untersuchungen. In: H. Meller (Ed.), Der geschmiedete Himmel: Die weite Welt im Herzen Europas vor 3600 Jahren (Begleitband zur Sonderausstellung, Landesmuseum für Vorgeschichte Halle (Saale) 15. Oktober 2004 - 24. April 2005, Dänisches Nationalmuseum Kopenhagen 1. Juli 2005 - 22. Oktober 2005, Reiss-Engelhorn-Museen Mannheim 4. März 2006 - 9. Juli 2006). Stuttgart 2004, 44-47.

SCHLOSSER 2010

W. Schlosser, Die Himmelsscheibe von Nebra - Astronomische Untersuchungen. In: H. Meller, F. Bertemes (Eds.), Der Griff nach den Sternen: Wie Europas Eliten zu Macht und Reichtum kamen. Internationales Symposium in Halle (Saale), 16.-21. Februar 2005. Tagungen des Landesmuseums für Vorgeschichte Halle 5, Halle (Saale) 2010, 913-933.

SCHMIDERER 2009

A. SCHMiderer, Geochemische Charakterisierung von Goldvorkommen in Europa. Dissertation, Martin Luther University Halle-Wittenberg, Halle (Saale) 2009. urn: urn:nbn:de:gbv:3:4-18 (last access 2.11.2020).

SCHÖNE 2015

T. SсHÖNE, Tatort Himmelsscheibe: Eine Geschichte mit Raubgräbern, Hehlern und Gelehrten. Halle (Saale) ${ }^{4} 2015$.

SCHWARZ 2016

R. Schwarz, Review of P. W. Stockhammer, K. Massy, C. Knipper, R. Friedrich, B. Kromer, S. Lindauer, J. Radosavljevic, F. Wittenborn, J. Krause, Rewriting the central European Early Bronze Age chronology: evidence from large-scale radiocarbon dating, PLoS ONE 10/10, 2015, 1-32, Jahresschrift für mitteldeutsche Vorgeschichte 95, 2016, 473-488.

SCHWARZ 2020

R. Schwarz, Zur Chronologie der Aunjetitzer Kultur in Mitteldeutschland, Studia Hercynia 23/2019, 2020, 36-53.

STÖLlnER 2009

T. StÖLlner, Prähistorische Montanreviere der Ost- und Südalpen - Anmerkungen zu einem Forschungsstand. In: K. OEGGL, M. Prast (Eds.), Die Geschichte des Bergbaus in Tirol und seinen angrenzenden Gebieten. Proceedings zum 3. Milestone-Meeting des SFB HiMAT vom 23.-26.10.2008 in Silbertal. Innsbruck 2009, 37-60.

StÖLLner, SCHWAB 2009

T. STÖLLnER, R. SCHWAB, Hart oder weich? Worauf es ankommt: Pickel aus dem prähistorischen Bergbau in den Ostalpen. In: A. Heinrich (Ed.), Festschrift für Fritz Eckart Barth zum 70. Geburtstag. Mitteilungen Anthropologischen Gesellschaft Wien 139, Horn - Vienna 2009, 149-166.

Stöllner, Hanning, Hornschuch 2011

T. StÖllner, E. Hanning, A. Hornschuch, Ökonometrie des Kupferproduktionsprozesses am Mitterberg Hauptgang. In: K. Oeggl, G. Goldenberg, T. Stöllner, M. Prast (Eds.), Die Geschichte des Bergbaus in Tirol und seinen angrenzenden Gebieten. Proceedings zum 5. Milestone-Meeting des SFB HiMAT vom 07.-10.10.2010 in Mühlbach. Innsbruck 2011, 115-128.

Straub 1980

D. Straub (Red.), Die Hallstatt-Kultur: Frühform europäischer Einheit (Exhibition catalogue, Steyr 1980). Linz 1980.

Timberlake, Hartgroves 2018

S. Timberlake, S. Hartgroves, New evidence for Bronze Age tin mining in Cornwall: the date of the antler pick from the Carnon valley streamworks, Devoran, near Truro, Cornish Archaeology $57,2018,107-122$.

WEISS 2017

R.-M. Weiss, Review of R. Gebhard, R. Krause (Eds.), Bernstorf: Archäologisch-naturwissenschaftliche Analysen der Gold- und Bernsteinfunde vom Bernstorfer Berg bei Kranzberg, Oberbayern, Munich 2016, Hammaburg N. F. 17, 2017, I-XIV.

Zschocke, Preuschen 1932

K. Zschocke, E. Preuschen, Das urzeitliche Bergbaugebiet von Mühlbach-Bischofshofen. Vienna 1932. 
Ernst Pernicka

Curt-Engelhorn-Centre for Archaeometry gGmbH D6, 3

68159 Mannheim

Germany

ernst.pernicka@cez-archaeometrie.de

iD orcid.org/0000-0003-4746-9239

Jörg Adam

Landeskriminalamt Brandenburg - Forensische Chemie

Tramper Chaussee 1

16225 Eberswalde

Germany

k-j.adam@kabelmail.de

Gregor Borg

Institute of Geosciences and Geography

Martin Luther University Halle-Wittenberg

Von-Seckendorff-Platz 3

06120 Halle (Saale)

Germany

gregor.borg@geo.uni-balle.de

Camborne School of Mines

University of Exeter

Penryn Campus

Penryn TR10 9FE

United Kingdom

orcid.org/0000-0001-8403-0650

Gerbard Brügmann

Curt-Engelhorn-Centre for Archaeometry gGmbH D6, 3

68159 Mannheim

Germany

gerbard.bruegmann@cez-archaeometrie.de

(iD) orcid.org/0000-0002-9904-0445

Jan-Heinrich Bunnefeld

State Office for Heritage Management and Archaeology Saxony-Anbalt

- State Museum of Prehistory Richard-Wagner-Straße 9 06114 Halle (Saale) Germany

jbunnefeld@lda.stk.sachsen-anbalt.de

D orcid.org/0000-0003-0941-4472

Wolfgang Kainz

State Office for Geology and Mining of the Federal State

of Saxony-Anbalt

Köthener Straße 38

06118 Halle (Saale)

Germany

kainz@lagb.mw.sachsen-anbalt.de
Mechtbild Klamm

State Office for Heritage Management and Archaeology

Saxony-Anbalt

- State Museum of Prebistory -

Richard-Wagner-Straße 9 06114 Halle (Saale)

Germany

mklamm@lda.stk.sachsen-anbalt.de

Thomas Koiki

State Office for Heritage Management and Archaeology

Saxony-Anbalt

- State Museum of Prehistory -

Richard-Wagner-Straße 9 06114 Halle (Saale)

Germany

tkoiki@lda.stk.sachsen-anbalt.de

Harald Meller

State Office for Heritage Management and Archaeology

Saxony-Anbalt

- State Museum of Prebistory Richard-Wagner-Straße 9 06114 Halle (Saale)

Germany

sekretariat@lda.stk.sachsen-anbalt.de

(D) orcid.org/0000-0002-7590-0375

Ralf Schwarz

State Office for Heritage Management and Archaeology

Saxony-Anbalt

- State Museum of Prehistory -

Richard-Wagner-Straße 9 06114 Halle (Saale)

Germany

rschwarz@lda.stk.sachsen-anbalt.de

Thomas Stöllner

Deutsches Bergbau-Museum Bochum

Am Bergbaumuseum 31 44791 Bocbum

Germany

thomas.stoellner@bergbaumuseum.de

Institute of Archaeological Studies

Rubr-University Bochum

Am Bergbaumuseum 31 44791 Bochum

Germany

orcid.org/0000-0001-8681-3632 
Christian-Heinrich Wunderlich State Office for Heritage Management and Archaeology Saxony-Anbalt - State Museum of Prehistory Richard-Wagner-Straße 9 06114 Halle (Saale) Germany cwunderlich@lda.stk.sachsen-anbalt.de

Alfred Reichenberger State Office for Heritage Management and Archaeology Saxony-Anbalt - State Museum of Prebistory Richard-Wagner-Straße 9 06114 Halle (Saale) Germany areichenberger@lda.stk.sachsen-anbalt.de (iD) orcid.org/0000-0001-9058-6444 